\title{
Cellulose-Based Hydrogels for Wastewater Treatment: A Concise Review
}

\author{
Maimuna Akter 1,+ ${ }^{+}$, Maitry Bhattacharjee ${ }^{2,+}$, Avik Kumar Dhar ${ }^{2}$, Fahim Bin Abdur Rahman 1,3 $\mathbb{D}$, \\ Siddika Haque ${ }^{4}$ (D), Taslim Ur Rashid ${ }^{5}$ (D) and S M Fijul Kabir ${ }^{5, *(D)}$
}

1 Department of Environmental Management, Independent University Bangladesh, Dhaka 1229, Bangladesh; maimuna_041@yahoo.com (M.A.); frahman@email.sc.edu (F.B.A.R.)

2 Department of Textile Engineering, Shyamoli Textile Engineering College, University of Dhaka, Dhaka 1207, Bangladesh; maitry1992moni@gmail.com (M.B.); avikkumardhar1990@gmail.com (A.K.D.)

3 Department of Chemical Engineering, University of South Carolina, Columbia, SC 29208, USA

4 Faculty of Textile Engineering, BGMEA University of Fashion and Technology, Dhaka 1230, Bangladesh; siddika@buft.edu.bd

5 Wislon College of Textiles, North Carolina State University, Raleigh, NC 27606, USA; turashid@ncsu.edu

* Correspondence: skabir@ncsu.edu

+ These authors contributed equally to this work.

check for

updates

Citation: Akter, M.; Bhattacharjee, M.; Dhar, A.K.; Rahman, F.B.A.; Haque, S.; Rashid, T.U.; Kabir, SMF. Cellulose-Based Hydrogels for Wastewater Treatment: A Concise Review. Gels 2021, 7, 30. https:// doi.org/10.3390/gels7010030

Received: 4 January 2021

Accepted: 16 March 2021

Published: 18 March 2021

Publisher's Note: MDPI stays neutral with regard to jurisdictional claims in published maps and institutional affiliations.

Copyright: (c) 2021 by the authors. Licensee MDPI, Basel, Switzerland. This article is an open access article distributed under the terms and conditions of the Creative Commons Attribution (CC BY) license (https:/ / creativecommons.org/licenses/by/ $4.0 /)$.
Abstract: Finding affordable and environment-friendly options to decontaminate wastewater generated with heavy metals and dyes to prevent the depletion of accessible freshwater resources is one of the indispensable challenges of the 21st century. Adsorption is yet to be the most effective and low-cost wastewater treatment method used for the removal of pollutants from wastewater, while naturally derived adsorbent materials have garnered tremendous attention. One promising example of such adsorbents is hydrogels (HGs), which constitute a three-dimensional polymeric network of hydrophilic groups that is highly capable of adsorbing a large quantity of metal ions and dyes from wastewater. Although HGs can also be prepared from synthetic polymers, natural polymers have improved environmental benignity. Recently, cellulose-based hydrogels (CBHs) have been extensively studied owing to their high abundance, biodegradability, non-toxicity, and excellent adsorption capacity. This review emphasizes different $\mathrm{CBH}$ adsorbents in the context of dyes and heavy metals removal from wastewater following diverse synthesis techniques and adsorption mechanisms. This study also summarizes various process parameters necessary to optimize adsorption capacity followed by future research directions.

Keywords: wastewater; heavy metal; dye; hydrogel; cellulose

\section{Introduction}

Water is the most abundant natural resource on the planet; however, only about 3\% of current water reserves are freshwater, while less than one-third of this freshwater is usable for different household, agricultural, and industrial activities [1-3]. While water demand enormously increases, the availability of freshwater is being exhausted because of an escalation in pollution, thus causing water scarcity for modern civilization [4,5]. Rapid industrialization, haphazard urbanization, and various anthropogenic activities along with improper waste disposal direct to such an increase in wastewater. Dyes and heavy metals are the two most typical contaminants found in industrial wastewater, which catastrophically affects sustainable ecosystems [6-9]. The existence of dyes, even at low concentrations, limits sunlight penetration into water that causes a significant reduction of dissolved oxygen, creating critical health risks to the aquatic living bodies. In many cases, dyes induce anaerobic digestion to produce different carcinogenic compounds, which can enter the food chain via aquatic organisms [10]. However, the amount of dye disposal into different water sources is still significant. For instance, over $7 \times 10^{5}$ tons of different reactive dyes are produced annually, whereas about $5-10 \%$ of these dyes end up in the 
industrial effluents [11]. Heavy metals, on the other hand, cause serious threats to human health because of their high carcinogenic and toxic nature. For example, a chronic intake of arsenic (As) can cause severe diseases such as kidney, prostate, bladder, or liver cancer. Chromium ( $\mathrm{Cr}$ ) is another highly toxic metal that unpleasantly affects human bodies as well as various aquatic species [12]. The hazardous nature of both dyes and heavy metals to public health and the natural ecosystem highlights the necessity of efficient treatment of industrial wastewater. Table 1 summarizes the adverse impacts of heavy metals and synthetic dyes on human health and the environment.

Table 1. Negative impacts of heavy metals and synthetic dyes on human health.

\begin{tabular}{|c|c|c|c|}
\hline & Pollutants & Potential Negative Impact on Human Health & Ref. \\
\hline \multirow{8}{*}{ 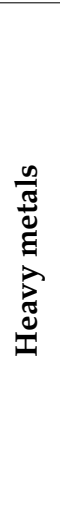 } & $\mathrm{Zn}$ & Stomach cramps, dermal irritations, vomiting, nausea, and anemia & [13] \\
\hline & $\mathrm{Cu}$ & Severe toxicological complications such as vomiting, cramps, convulsions, and even death & [14] \\
\hline & $\mathrm{Ni}$ & Acute lung, kidney and gastrointestinal pain, pulmonary fibrosis, and skin dermatitis & [15] \\
\hline & $\mathrm{Hg}$ & Pulmonary, kidney, and chest pain, dyspnea impairments & [16] \\
\hline & Co & $\begin{array}{c}\text { Paralysis, asthma, pneumonia, diarrhea, lung irritations, weight loss, vomiting, nausea, } \\
\text { damage thyroid hormone and liver }\end{array}$ & [17-19] \\
\hline & $\mathrm{Cd}$ & Renal dysfunction and even death & [13] \\
\hline & $\mathrm{Pb}$ & $\begin{array}{l}\text { Fauilure of kidney, liver, reproductive system, basic cellular processes, brain function, and } \\
\text { even the central nervous system of the human body }\end{array}$ & [20-22] \\
\hline & $\mathrm{Cr}$ & Destruction of human metabolism, food chain disruption, skin irritation, lung carcinoma & {$[23,24]$} \\
\hline \multirow{5}{*}{ 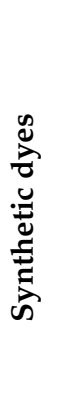 } & Azo dyes & $\begin{array}{c}\text { DNA destruction, carcinogenic and mutagenic, skin irritation, hypertension, tongue and } \\
\text { larynx distress, blindness, acute tubular necrosis, gastritis, respiratory distress, liver issues, } \\
\text { bladder cancer, neurosensory harm }\end{array}$ & {$[25-30]$} \\
\hline & Reactive dyes & $\begin{array}{c}\text { Respiratory diseases, asthma, coughing, wheezing, sneezing, watery eyes, itching, respiratory } \\
\text { sensitization, poor immune system, deteriorate the water quality and damages to water } \\
\text { bodies, ecosystem and biological cycle }\end{array}$ & [31-33] \\
\hline & Vat dyes & Skin irritation & [33] \\
\hline & Sulfur dyes & Unpleasant odor, carcinogenic, skin irritation, allergic dermatitis, mutations & {$[34,35]$} \\
\hline & Disperse dyes & Bioaccumulation in nature, genotoxic in mammalian assays, mutagenic & [36] \\
\hline
\end{tabular}

Adsorption is the most common and effective method used for wastewater treatment because it is convenient, simple, less expensive, and has no harmful by-products [37-40]. Activated carbon as an adsorbent is highly efficient that is often used commercially to remove pollutants from wastewater. However, the excessive cost and complicated regeneration process limit the widespread utilization of activated carbon for wastewater treatment [41]. Although recent studies have discovered numerous adsorbents for the removal of dyes and heavy metals from industrial effluent, the use of these adsorbents for bulk treatment of wastewater is still challenging [42,43]. HGs are three-dimensional polymer networks, have attracted incredible attention nowadays to eliminate contaminants from waste streams due to their high removal efficiency [44-47]. HGs are highly porous and comprised of numerous hydrophilic functional groups (e.g., $-\mathrm{OH},-\mathrm{COOH},-\mathrm{NH}_{2}$, $-\mathrm{SO}_{3} \mathrm{H},-\mathrm{CONH}_{2}$, etc.) that enable the adsorption and retention of a large volume of water during the treatment process and eventually cause up to the complete removal and recovery of aqueous dyes and heavy metals $[48,49]$. However, most of the existing HGs are derived from petrochemicals, which are neither renewable nor biodegradable. CBHs derived from cellulose, the most abundant polymer in nature, are superabsorbent, durable, biodegradable, biocompatible, and non-toxic [50]. Recently, researchers have reported almost complete removal of dyes and heavy metals from wastewater using different CBHs. For instance, Zhou et al. [51] achieved $\approx 90 \%$ of $\mathrm{Pb}^{+2}$ removal efficiency (adsorption capacity of $171 \mathrm{mg} / \mathrm{g}$ ) within four hours of the adsorption process using carboxylated 
cellulose nanofibril-based hydrogels. Such high adsorption values were also obtained for $\mathrm{Cu}^{2+}(182-230 \mathrm{mg} / \mathrm{g}), \mathrm{Ni}^{2+}(200 \mathrm{mg} / \mathrm{g})$, and $\mathrm{Hg}^{2+}(140 \mathrm{mg} / \mathrm{g})$ using different types of CBHs [51-54] Recently, Deng et al. [55] successfully removed almost $100 \%$ Congo Red dyes with $166.1 \mathrm{mg} / \mathrm{g}$ saturation adsorption using chitosan and cellulose. Numerous scopes of using CBHs still exist, since the modification of HG functional groups enhances its adsorption effectiveness.

While numerous research works have been published using CBHs to treat wastewater streams, the lack of review in this specific area is the motivation of the present work. Table 2 demonstrates the gap in the literature based on the recently published review articles that are closely aligned to the proposed topic. A recently published book chapter has covered a few parts of the topic; however, it lacks the critical content, such as different adsorption mechanisms required to develop a comprehensive understanding of the topic [56]. This review is systematically designed to include critical information on the topic such as the development of $\mathrm{CBH}$ for the dye and heavy metal adsorption from industrial effluent, adsorption mechanism, and factors affecting the adsorption capacity along with future outlook.

Table 2. Recently published review articles on wastewater treatment using hydrogels.

\begin{tabular}{|c|c|c|c|}
\hline Types of Hydrogel & Types of Pollutants & Major Contents & Ref. \\
\hline Synthetic and natural hydrogels & Heavy metal & Selectivity, efficiency, and reusability & [57] \\
\hline Synthetic and natural hydrogels & Heavy metal & $\begin{array}{l}\text { Factors of adsorption and detection of } \\
\text { metal }\end{array}$ & [58] \\
\hline Synthetic and natural hydrogels & $\begin{array}{l}\text { Aqueous pollutants including } \\
\text { dye, heavy metals, and anions }\end{array}$ & $\begin{array}{c}\text { Adsorption kinetics, regeneration, and } \\
\text { reusability }\end{array}$ & [49] \\
\hline Synthetic and natural hydrogels & $\begin{array}{l}\text { Dye, heavy metal, radioactive } \\
\text { materials, pesticides }\end{array}$ & $\begin{array}{l}\text { Adoption properties, kinetics, isotherm, } \\
\text { mechanism, factors, recycling, and } \\
\text { recovery }\end{array}$ & {$[59]$} \\
\hline Synthetic and natural hydrogels & Dye and metal & $\begin{array}{l}\text { Synthesis, mechanism, modification of } \\
\text { adsorbents, and kinetics }\end{array}$ & {$[60]$} \\
\hline Acrylic-based hydrogels & Dye and heavy metals & $\begin{array}{c}\text { Preparation and adsorption properties of } \\
\text { different acrylic-based HG }\end{array}$ & [61] \\
\hline Hybrid hydrogels & $\begin{array}{l}\text { Metal, radionuclides, anions, } \\
\text { acid phenol ammonium }\end{array}$ & Adsorption properties & [62] \\
\hline Composite hydrogels & Dye & $\begin{array}{l}\text { Adsorption properties of different types of } \\
\text { composite hydrogels }\end{array}$ & [63] \\
\hline Cellulose-based hydrogel & Dye and metal & $\begin{array}{l}\text { Preparation, adsorption mechanisms, and } \\
\text { factors affecting adsorption capacity }\end{array}$ & This paper \\
\hline
\end{tabular}

\section{Preparation of $\mathrm{CBH}$}

A plethora of challenges generated by the excessive use of fossil resources and nonbiodegradable materials result in shifting the attention of researchers toward renewable and environmentally safe materials. At this juncture, biopolymers are used in different areas such as agriculture, food packaging, biomedical applications, and wastewater treatment $[55,64-70]$. Similarly, when it comes to the removal of dyes and heavy metals by adsorption process, biopolymer-based hydrogels such as CBHs are suitable due to their better functionality, good solubility in organic solvents, enhanced surface area, abundancy, low-cost, better adsorption capacity, biodegradability, and ease of fabrication and recyclability. Additionally, the excellent hydrophilicity makes the CBHs a promising adsorbent for wastewater treatment [71-73]. However, the performance of an adsorbent for the removal of pollutants from wastewater is highly selective to the physical and chemical properties of the adsorbent materials [47]. Therefore, the first and foremost step for an effective 
adsorption process is to synthesize a suitable $\mathrm{CBH}$ adsorbent having high adsorbability to the dyes and heavy metal ions present in wastewater streams.

CBHs are typically derived from cellulose (i.e., native/pure cellulose and bacterial cellulose), its derivatives (ether derivatives: methylcellulose, ethylcellulose, hydroxyethyl methylcellulose, hydroxypropyl cellulose, carboxymethyl cellulose (CMC), etc.; ester derivatives: acetate trimellitate, acetate phthalate, hydroxypropyl methyl phthalate, hydroxypropyl methyl phthalate acetate succinate, etc.), and/or its composites (such as polyelectrolyte complex, interpenetrating polymer networks and blending with other polymers) [48,74]. One of the greatest challenges of HG synthesis from these base materials is dissolution in a common solvent; while some of the cellulose derivatives are water-soluble, native/pure cellulose is hardly soluble in most common organic and inorganic (e.g., water) solvents. Consequently, a suitable solvent is a prerequisite for $\mathrm{CBH}$ synthesis that includes alkali/urea (or thiourea), $\mathrm{LiCl} /$ dimethylacetamide, N-methyl morpholine-N-oxide, and ionic liquids.

A stable 3D network structure of HG that is critical to hold a huge amount of water in their interstitials is achieved by crosslinking the constituting polymer chains [74,75]. Cellulose has hydrophilic functional groups, such as hydroxyl $(-\mathrm{OH})$, that enable them to form both physical crosslinking (electrostatic interaction) and chemical crosslinking (covalent interaction using crosslinker). Depending on the materials used and modes of fabrication, different types of interactions are observed in CBHs, such as (i) small cationscellulose (electrostatic interaction), (ii) polycations-cellulose (electrostatic interaction), (iii) polymer-cellulose (H-bond or hydrophobic interaction), (iv) self-assembly, (v) coordination complex crosslinking, and (vi) covalent crosslinking [76]. Figure 1A illustrates different types of interactions between cellulose molecules and other polymers or small molecules within a hydrogel matrix. All these interactions lead to the formation of the crosslinked structure of the hydrogels that prevents the complete destruction and dissolution of the CBHs during swelling. Cellulose-based hydrogels can be designed in a variety of physical shapes, including spherical, cylindrical, bead, blocks, microparticles, nanoparticles, and films by diverse methods of fabrication.

Figure 2 shows different pathways of synthesis of CBHs. Supplementary Materials Tables S1 and S2 include recent works on heavy metal and dye removal using CBHs along with their adsorption capacities.

\subsection{Physical Path of Crosslinking}

However, physical crosslinking process held by weak connections such as hydrogen bonds (H-bond), ionic interactions, hydrophobic interactions, $\pi-\pi$ interactions, and van der Waals forces [72,77-83] is often more favorable for ecofriendly and non-toxic HG synthesis, as it does not involve use of chemical-based crosslinking agents [84] Although CBHs developed by the physical crosslinking process suffer from poor mechanical properties, they are widely used for adsorption purposes because of their high porosity having a higher chance to adsorb more pollutants, low sensitivity to $\mathrm{pH}$, ease of regeneration (being reversible process), and no reduction in adsorption capacity due to potential reaction with a crosslinker as in the chemical process $[60,85,86]$. These HGs are prepared in the following methods.

\subsubsection{Freeze-Thaw}

One of the physical methods to prepare HGs is crystallization by the freeze-thaw technique [83]. In the freeze-thaw technique, crystallization occurs by freezing bulk solvents or low molecular solutes that increase the concentration of polymer by minimizing the chain space in the polymer and enable the chains to align and connect to each other to form a network structure (illustrated in Figure 1B) [75,87]. Freeze-thaw cycles allow a porous structure to be created in HGs because of the space left from the melting crystals at thawing stages $[87,88]$. The mechanical properties of the freeze-thawed HGs can be 
modulated by altering the concentration of polymers, the number of freeze-thaw cycles, the freezing and thawing time, and the freezing temperature [89].

HGs prepared by the freeze-thaw process show better elastic properties than that of the HGs prepared by chemical methods and hence drawing large-scale attention around the world [90]. Bio-compatible and non-toxic polysaccharide-based (such as cellulose, dextran, pullulan, and carboxymethyl curdlan, CMC, etc.) HGs are developed following this process [91]. For example, PVA (poly vinyl alcohol)/CMC HGs are prepared by freeze-thaw processes and applied to adsorb heavy metal ions including $\mathrm{Ag}^{+}, \mathrm{Ni}^{2+}, \mathrm{Cu}^{2+}$, and $\mathrm{Zn}^{2+}$ [87].

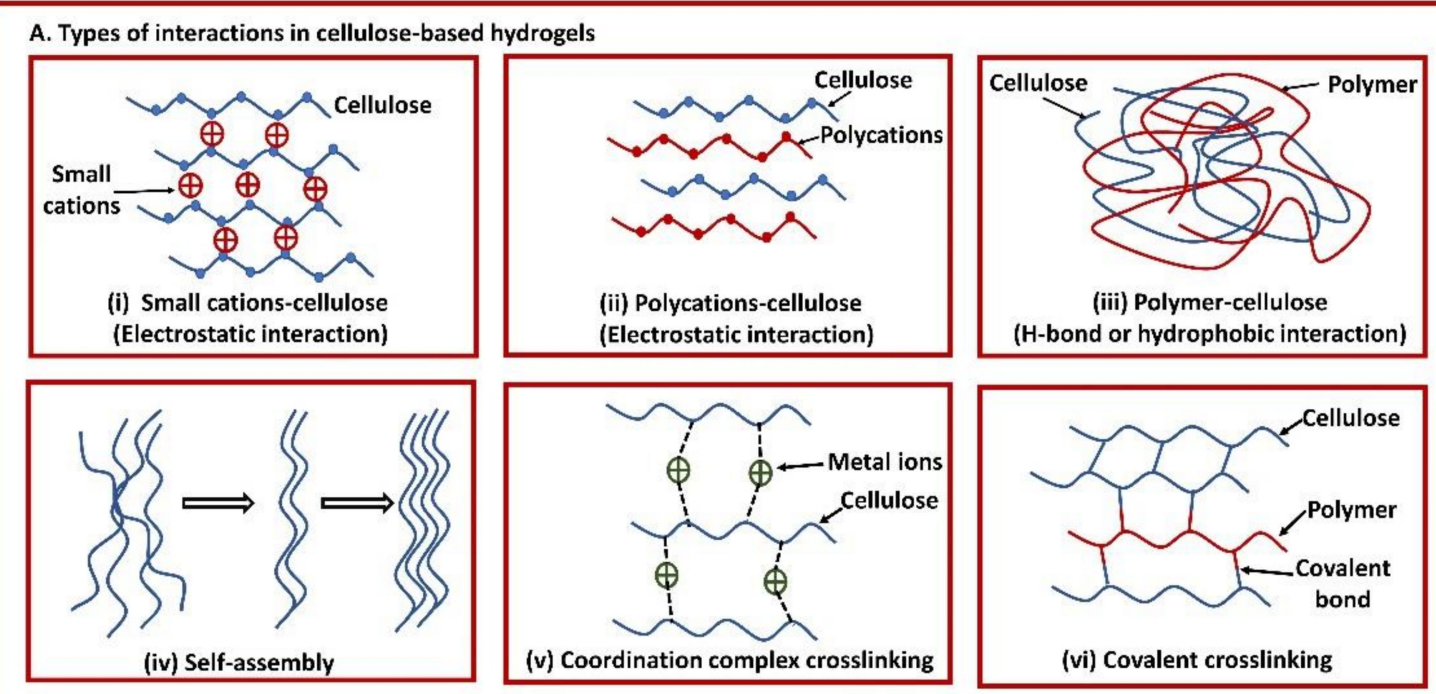

B. Example of physical crosslinking (Freeze-thaw)
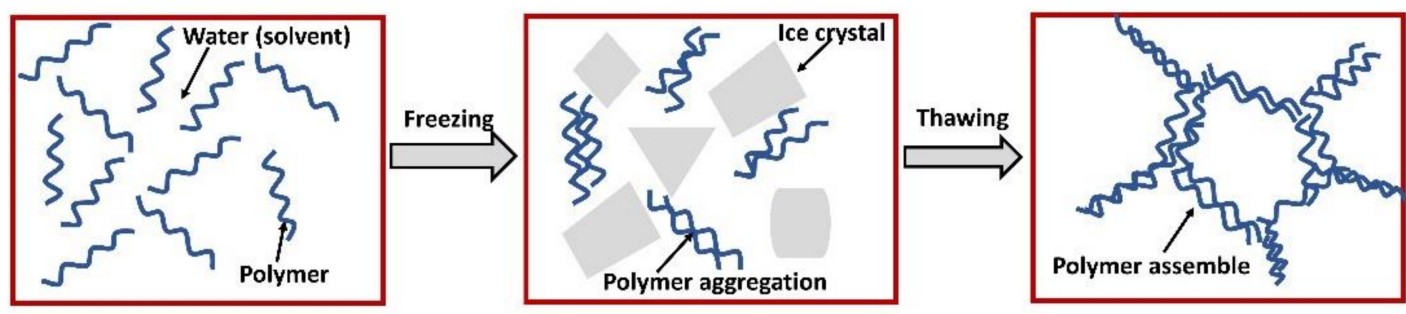

Figure 1. Illustration of (A) interactions in cellulose-based hydrogels in different systems-physical crosslinking (i-v) and chemical crosslinking (vi), and (B) an example of physical crosslinking (freeze-thaw). (A) (i) Electrostatic interaction between small cations and cellulose chain; (ii) electrostatic interaction between opposite charges of polycation molecule and cellulose chain; (iii) H-bond or hydrophobic interaction between polymer molecule and cellulose chain; (iv) self-assembly of cellulose molecules to fold into scaffolds by weak non-covalent bonding mechanisms-including hydrogen bonds, van der Waals forces, and hydrophobic interactions; (v) coordination complex crosslinking between multivalent metal ions and cellulose chain; and (vi) covalent crosslinking among functional moieties of cellulose chains and/or polymer chains, sometimes with the help of crosslinkers. (B) Fabrication of hydrogels through physical crosslinking by freeze-thaw method.

\subsubsection{Self-Assembling}

The idea of using self-assembled $\mathrm{CBHs}$ preparation has grabbed the attention of researchers, as it does not need any crosslinkers to prepare. Self-assembling HGs are developed when the constituting monomers in the form of fibrils are assembled via noncovalent interactions (van der Waals forces, electrostatic interactions, hydrogen bonding, and $\pi-\pi$ stacking interactions) followed by the entanglement of the fibrils into a robust network [92]. The mechanical properties of these HGs can be tuned by changing the concentration of the constituting monomers. Cationic guar gum (CGG) and TEMPO $(2,2,6,6-$ 
tetramethylpiperidine-1-oxyl)-oxidized cellulose nanofibers (TOCN) can instantaneously form HGs as soon as they come in contact with each other. Formed HGs can adsorb metal ions as well as dyes from wastewater. They can also be used to treat oily wastewater by coating filter papers in a layer-by-layer deposition process [71].

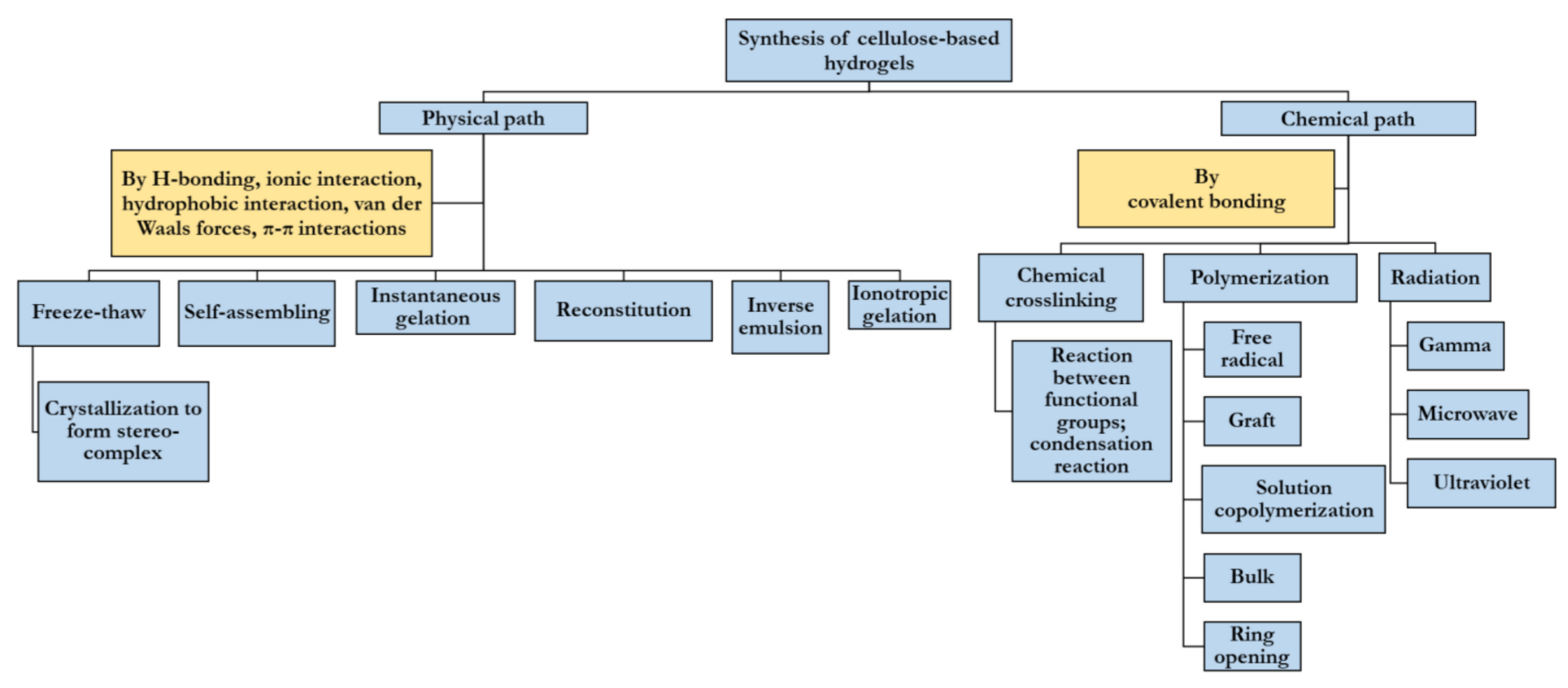

Figure 2. Physical and chemical paths of cellulose-based hydrogel (CBH) synthesis.

\subsubsection{Instantaneous Gelation}

The instantaneous gelation method is another way to develop HG instantly following the one-step method $[93,94]$. Magnetic chitosan-based HG beads (m-CS/PVA/CCNFs), consisting of carboxylated cellulose nanofibrils (CCNFs), amine-functionalized magnetite nanoparticles, and poly (vinyl alcohol) (PVA) blended chitosan, have been prepared by the instantaneous gelation method as adsorbents for $\mathrm{Pb}(\mathrm{II})$. The prepared $\mathrm{HG}$ beads can be persevered in distilled water for future use and recovered with the aid of a magnet if required [51].

\subsubsection{Reconstitution}

Cellulose-based composite HGs are prepared by the reconstitution method that often uses ionic liquid as a solvent. Here, the composite HG is held by a strong intermolecular Hbond that eventually contributes to the tensile strength of the developed HG. For instance, biodegradable collagen/cellulose HG beads (CCHBs) have been prepared by reconstitution from a 1-butyl-3-methylimidazolium chloride $\left(\left[\mathrm{C}_{4} \mathrm{mim}\right] \mathrm{Cl}\right)$ solution that can potentially be used to adsorb both dyes and heavy metals [95].

\subsubsection{Inverse Emulsion Technique}

Water-in-oil emulsion refers to a phenomenon that occurs when water droplets are dispersed in oil (the continuous phase: paraffin oil) by using a suitable stabilizing agent (such as non-ionic surfactant Triton X-100), and then the system undergoes phase inversion in a coagulation bath to leach out the droplets and precipitates the porous film. This mechanism is widely known as the inverse emulsion technique. Partially hydrolyzed polyacrylamide grafted Arabic gum (AG-g-PAM/PAA)-based HG has been prepared by the inverse emulsion technique that can be used for dye and metal ion adsorption. This HG showed the adsorption of Methylene Blue (MB) with a capacity of $200 \mathrm{mg} / \mathrm{g}$ from an aqueous solution. The results revealed an ability of the novel porous HG to adsorb $99 \%$ of dye in only $10 \mathrm{~min}$ [96]. In addition to that, HGs based on sodium carboxymethyl cellulose and acrylic acid were prepared by inverse emulsion polymerization using potassium 
persulfate as an initiator and $\mathrm{N}, \mathrm{N}^{\prime}$-methylenebisacrylamide as a crosslinker. The maximum swelling capacity for the HGs was $544.95 \mathrm{~g} / \mathrm{g}$ in distilled water and $44.0 \mathrm{~g} / \mathrm{g}$ in $0.9 \% w / v$ $\mathrm{NaCl}$ solution [97].

\subsubsection{Ionotropic Gelation}

The ionotropic gelation (IG) technique allows the production of nanoparticles and microparticles by electrostatic interactions between two ionic species under certain conditions where at least one of the species should be a polymer [98]. CBH beads are successfully synthesized by the ionotropic gelation of sodium alginate (SA) and hydroxypropyl cellulose (HPC) solutions with varying ratios (0:50, 75:25, and 100:0) followed by extrusion through a syringe to form HG beads. The adsorption property of the produced bead is largely influenced by the concentrations of SA and HPC. The beads showed $47.72 \mathrm{mg} / \mathrm{g}$ adsorption capacity and a $95.45 \%$ adsorption percentage of $\mathrm{Pb}^{2+}$ [99]. Cellulose nanocrystals and alginate-based HG beads are also synthesized by the ionotropic gelation that can be used for the adsorption of organic dyes [100].

\subsection{Chemical Path of Crosslinking}

Chemical crosslinking is preferred when high mechanical strength is required through introducing a chemical crosslinking agent forming strong molecular bonds such as via covalent and electrostatic interactions. However, the degree of crystallinity negatively impacts the adsorption capacity and swelling ratio due to the reduced pore size and rigidity of polymer chains [61]. In addition, crosslinking agents and the higher crosslinking density engage some binding sites of the adsorbent; therefore, there should be a balance between maintaining the required mechanical strength and maximizing the adsorption capacity $[60,61]$. The chemical path of crosslinking can be achieved in the following ways.

\subsubsection{Crosslinking by Chemical Reaction}

In chemical crosslinking, the bond is formed between the crosslinking agent and polymer or among the functional groups of polymer molecules. A polymer having hydroxyl (such as cellulose and its derivatives) and amine (such as chitosan, proteins) groups are connected with crosslinker having an aldehyde group (aldol formation) via covalent bond [75]. HG formation for the polymers with $-\mathrm{OH}$ groups requires specific conditions such as lower $\mathrm{pH}$, high temperature, and methanol as a quencher, whereas protein-based HGs can be formed in normal conditions [61,101-103]. A typical crosslinker for CBHs includes glutaraldehyde and epichlorohydrin, formaldehyde, acetaldehyde due to their availability, and cost-effectiveness $[61,75,104]$. For instance, environment-friendly CBH beads have been produced from $\mathrm{CMC}$ by using an epichlorohydrin $(\mathrm{ECH})$ crosslinker in an inverse suspension (fluid wax) crosslinking mechanism, where ether linkage is developed between ECH and CMC contributing to high porosity in the structure of HG. More specifically, the porous structure of the HG is attributed to the presence of numerous carboxylate anions $\left(-\mathrm{COO}^{-}\right)$in a network of $\mathrm{HG}$ beads, which not only helps expand the HG network but also increases the size and amount of pore enabling more metal ion to anchor [105]. Ge et al. also prepared a high-performance composite hydrogel (cellulose/poly-ethylene imine (PEI)) by grafting hyperbranched PEI onto cellulose chains using an ECH crosslinker [106]. The hydrogels showed excellent $\mathrm{Cu}^{2+}$ ion removal capacity (ca. $285.7 \mathrm{mg} / \mathrm{g}$ ) and good stability over a wide range of $\mathrm{pHs}$ and temperatures due to the chemical crosslinking facilitated by ECH. Similarly, in the presence of a crosslinker, condensation and additional reactions occur between polymers having amine and ester moieties, and a crosslinker, causing Schiff base formation [107].

\subsubsection{Crosslinking by Polymerization}

A large number of $\mathrm{CBHs}$ are synthesized by the chain growth polymerization process, which is accomplished in three steps including initiation, propagation, and termination [49]. Among different types of polymerization processes, free radical is characterized by a faster 
synthesis process, ease of implementation under various reaction conditions, wide-ranging temperatures, and low costs, and it is widely followed for HG preparation [75,108]. Here, for the initiation step, a free radical is generated from the initiator such as potassium persulphate (KPS), tetramethylene-diamine (TEMED), ammonium persulfate (APS), etc., in the presence of some conditions in term of light, pressure, temperature, and radiations. In propagation, polymer chain growth occurs, and the crosslinker reacts with the growing polymer chain, randomly leading to forming a 3D network structure, followed by the termination of the polymerization via combination or disproportion $[49,60,61]$. Cellulose-graft-acrylic acid (C-g-AA) HGs are prepared via free-radical polymerization in $85 \%$ phosphoric acid solution in the presence of $50 \mathrm{mg}$ ammonium persulfate (APS) as an initiator and $10 \mathrm{mg} \mathrm{N}, \mathrm{N}^{\prime}$-methylene bisacrylamide (MBA) as a crosslinker. Acrylic acid acts as a grafting monomer and can bind heavy metal ions and dyes through its carboxyl groups. The mechanism behind the HG preparation is the extraction of hydrogen atoms from the cellulose molecules to produce cellulose macro-free radicals on the cellulose chains using peroxodisulphate $\left(\mathrm{S}_{2} \mathrm{O}_{8}{ }^{2-}\right)$ [52]. In another study, a similar type of hydrogel was prepared from cellulose and CMC separately or in a mixture of both of them by polymerization with partially neutralized AA [109]. The polymerization was initiated by KPS, and vinylsulfone (VS), glutaraldehyde, MBA, and ECH were used as crosslinkers. The hydrogel was successfully used to remove and recover heavy metals such as $\mathrm{Cu}$ (II) from wastewater. The addition of a modifier such as tannic acid (TA) to cellulose-based hydrogel can be helpful to attain a homogeneous pore structure of the hydrogel that improves the adsorption performance. Ning et al. [110] synthesized an HEC-co-p(AA-AM)/TA (HEC: hydroxyethyl cellulose, and AM: acrylamide) hydrogel by the grafting of AA and AM onto HEC, followed by modification with TA. The hydrogel showed excellent MB adsorption performance (ca. $3438.27 \mathrm{mg} / \mathrm{g}$ ) with high reusability. In a recent study, a novel fluorescent lignin-based hydrogel with cellulose nanofibers and carbon dots (CDs) was synthesized by free radiacal polymerization [111]. The hydrogel demonstrated 3D porous structures that provided many active sites and ion transport channels, thereby improving the adsorption performance for hexavalent chromium $(\mathrm{Cr}(\mathrm{VI})$ ) (maximum adsorption capacity $599.9 \mathrm{mg} / \mathrm{g})$.

\subsubsection{Crosslinking by Radiation}

It is also a polymerization process, where no chemical-based crosslinker or catalyst is used. Instead of a chemical crosslinker as in the usual polymerization process mentioned above, it induces different types of radiations (such as gamma, electron beams, microwave, and ultraviolet radiations) to crosslink the polymer chains. Therefore, it is an environmentally benign synthesis process involving zero waste generation [60,61]. CMC-Na is a widely used derivative of cellulose, which is synthesized by gamma irradiation [53].

\section{Adsorption Mechanism}

A comprehensive understanding of the adsorption process along with the removal mechanism of several pollutants on respective $\mathrm{CBHs}$ is very indispensable for further modification of $\mathrm{CBHs}$ to improve their adsorption performance. The adsorption by $\mathrm{CBHs}$ typically occurs through different types of interactions, which are extensively dependent on the functional groups present in the HG, adsorbent properties, the chemical composition of pollutants, and experimental parameters (i.e., initial pollutant concentration, solution $\mathrm{pH}$, temperature, the coexistence of metal ions, etc.) [60]. The most common adsorption mechanism for the removal of dyes and heavy metals by CBHs is electrostatic interactions; however, combinations of other interactions along with electrostatic interaction are also reported in many adsorption processes [105,112-114]. The different adsorption mechanisms of dyes and heavy metals by CBHs are shown in Figures 3 and 4 . 


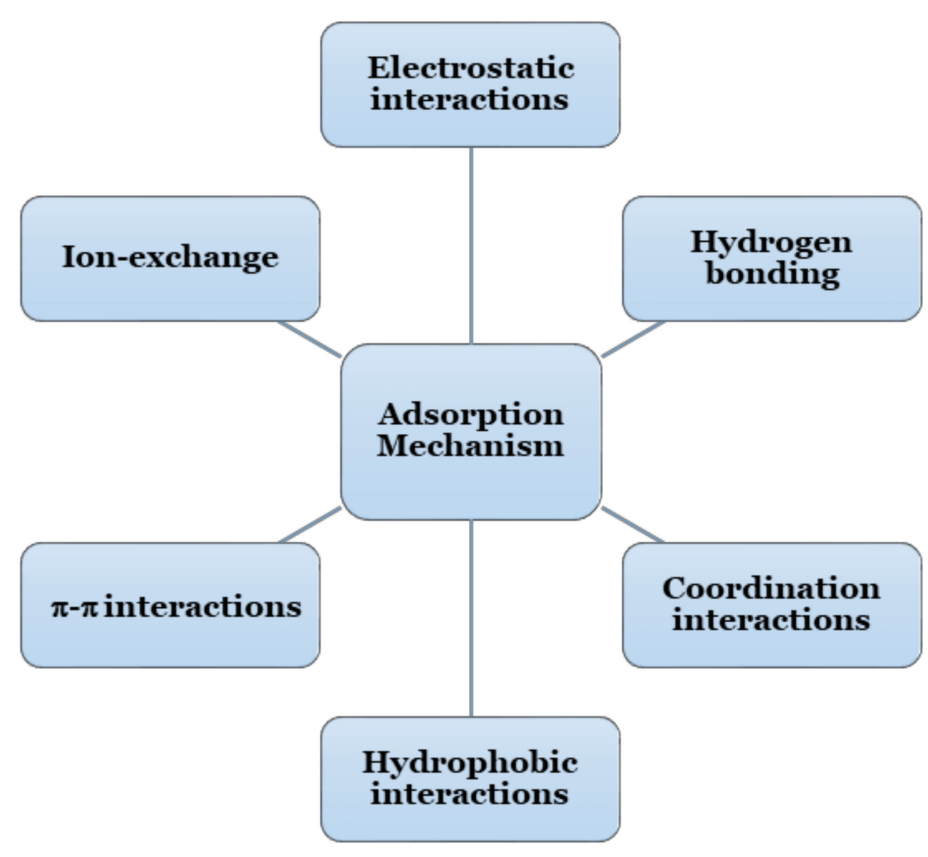

Figure 3. Adsorption mechanism of dyes and heavy metals by CBHs.

\subsection{Electrostatic Interactions}

Electrostatic interaction comprises the interaction between charged modules; attractive and repulsive interaction occurs when molecules are oppositely-charged (cation-anion interactions) and similarly-charged (cation-cation or anion-anion interactions), respectively [115]. To remove ionic contaminants electrostatically by $\mathrm{CBHs}$, the adsorbent surface must oppositely be charged to the respective ions that need to be adsorbed. Based on the pollutant nature and chemical properties, the $\mathrm{CBHs}$ are synthesized with specific functional groups, which are capable of producing the opposite charge corresponding to target ions [60]. Additionally, the formation of charged species on the adsorbent surface intensely depends on the $\mathrm{pH}$ of the solution [116]. $\mathrm{pH}_{\mathrm{PZC}}$ represents the $\mathrm{pH}$ of the solution when no charge species exist on the adsorbent surface [117-119]. At $\mathrm{pH}>\mathrm{pH}_{\mathrm{PZC}}$, functional groups, such as $-\mathrm{COOH},-\mathrm{OH}$, and $-\mathrm{H}_{3} \mathrm{PO}_{4}$ are deprotonated due to an excessive concentration of $\mathrm{OH}^{-}$in the aqueous solution that creates anions (such as $-\mathrm{COO}^{-},-\mathrm{O}^{-}$, $-\mathrm{PO}_{4}{ }^{3-}$, etc.) on the adsorbent surface, resulting in attractive interactions between cationic contaminants and the anionic adsorbent surface (Figure 4). In contrast, the adsorbent surface is positively charged $\mathrm{pH}<\mathrm{pH}_{\mathrm{PZC}}$ due to the protonation of functional groups (i.e., $-\mathrm{NH}_{2},-\mathrm{SH}$, etc.) on the adsorbent surface as a consequence of an increase in $\mathrm{H}^{+}$ concentration in the solution. Here, a recent study also found the highest electrostatic interactions between a high-capacity $\mathrm{HG}$ with $-\mathrm{NH}_{2}$ groups and an anionic dye (Acid Black 1) at low $\mathrm{pH}$ conditions, which was decreased with rising $\mathrm{pH}$ and reached the least interactions for very high $\mathrm{pH}$ condition [112]. In another study, CMC adsorbed the utmost amount of $\mathrm{Pb}^{2+}, \mathrm{Cu}^{2+}$, and $\mathrm{Ni}^{2+}$ from aqueous solution through electrostatic interactions at higher $\mathrm{pH}$ [105]. Similar electrostatic nature was perceived for the removal of MB (a cationic dye) by chemi-mechanical pretreated cellulose-based superabsorbent hydrogel [97]. Hu et al. [120] also observed electrostatic adsorption with complexation between - $\mathrm{OH}$ and $-\mathrm{COOH}$ functional groups of sodium alginate-CMC-cellulose gel beads for the removal of $\mathrm{Pb}^{2+}$. 


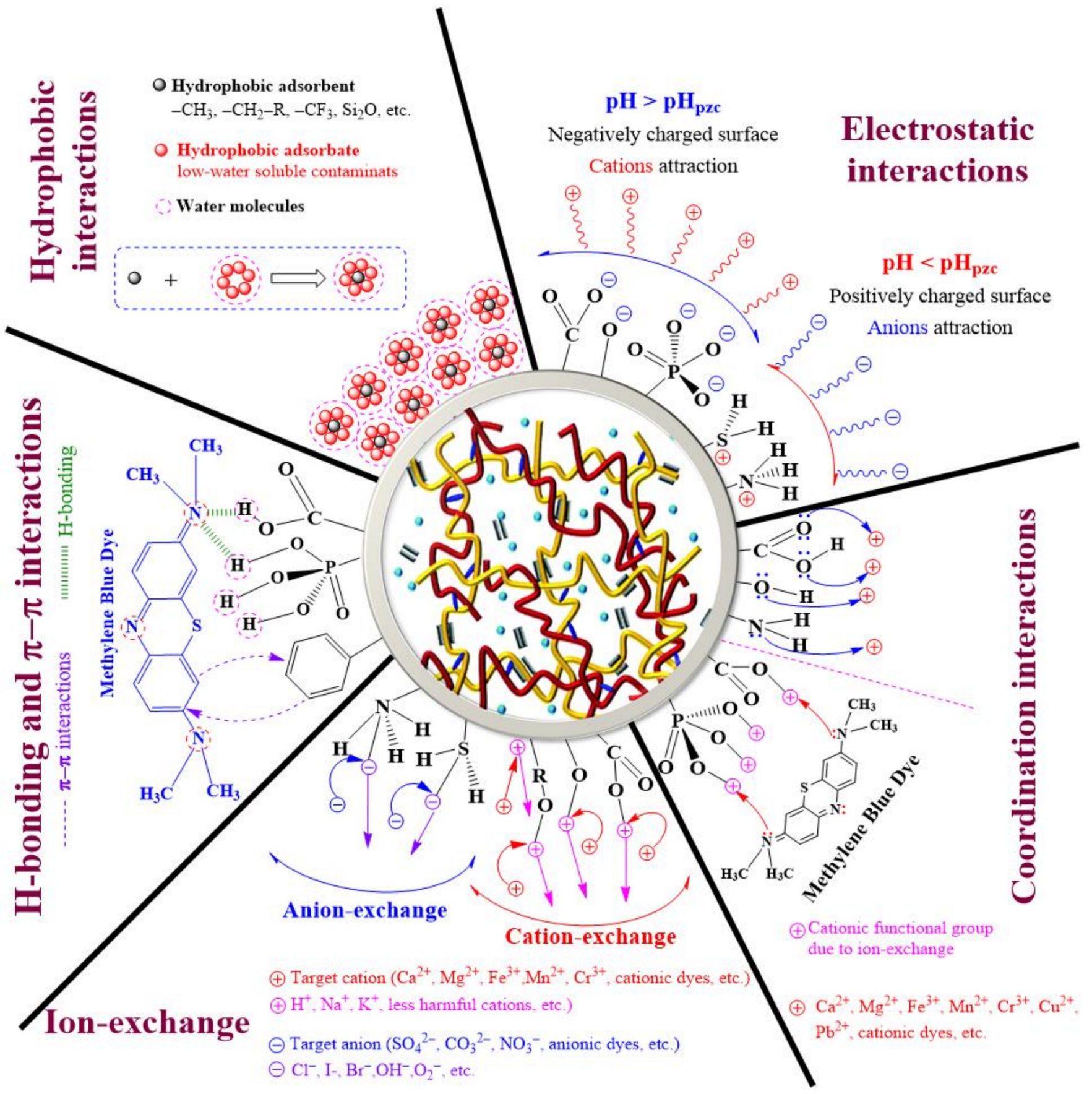

Figure 4. Adsorbent-adsorbate interaction mechanisms for the decontamination of wastewater by CBHs.

\subsection{Ion Exchange}

Ion exchange refers to an exchange of ions between a liquid (wastewater) and an insoluble solid (adsorbent). Unwanted dissolved ions (cations or anions) in an aqueous solution are removed and replaced with ions of the same charge on the adsorbent surface. In a perfect ion-exchange process, the number of ions released from the adsorbent surface is equivalent to the number of ions adsorbed by the adsorbent molecules [121]. Ion exchange is a very convenient and efficient tool especially for the removal of hazardous pollutants, such as dyes and heavy metals from wastewater. This process decreases the degree of hazardous load by transforming pollutants into a shape in which they can be recycled, leaving behind less harmful elements in their place or enable ultimate discharge by decreasing the hydraulic flow of the stream carrying toxic elements. In addition, the 
ion-exchange process has the capability to discrete as well as distillate contaminants [122]. Similar to electrostatic interactions, ion-exchange mechanism also shows a strong dependency on the $\mathrm{pH}$ of the solution. At $\mathrm{pH}<\mathrm{pH}_{\mathrm{PZC}}$, the functional groups of adsorbent are positively charged because of an increase in $\mathrm{H}^{+}$concentration, resulting in cations exchange. On the other hand, functional groups are negatively charged when $\mathrm{pH}>\mathrm{pH}_{\mathrm{PZC}}$, which causes anions exchange (Figure 4) [123]. Zhou et al. [124] observed ion exchange and chelation between positively charged ions $\left(\mathrm{Cd}^{2+}, \mathrm{Ni}^{2+}\right.$, and $\left.\mathrm{Pb}^{2+}\right)$ and ionized/non-ionized carboxylic groups within the HG during the removal of these metal ions from aqueous solutions using cellulose-graft-acrylic acid hydrogel at $\mathrm{pH}$ 2.5-6.0, since-COOH groups in the $\mathrm{HG}$ surface are protonated at lower $\mathrm{pH}$, which replaced metal ions with $\mathrm{H}^{+}$from - $\mathrm{COOH}$ groups. In another investigation, $\mathrm{Ca}^{2+}$ ions replaced cations from cellulose-graftpolyacrylamide/hydroxyapatite composite HG and attached to the hydroxyapatite surface through an ion-exchange mechanism [125]. Xiong et al. [126] developed a self-cleaning hybrid (cellulose-titanate) hydrogel microsphere by a simple sol-gel process that exhibits an excellent ability to remove heavy metal from oily wastewater. The strong physical and chemical interaction between titanate nanotubes (TNTs) and cellulose fibers helped inherit and integrate the intrinsic properties of both titanate and cellulose hydrogels. At first, the heavy metal ions $(\mathrm{Cu}(\mathrm{II}))$ were adsorbed on the inside of the hydrogel under the electrostatic interaction. Then, through ion exchange, $\mathrm{Cu}(\mathrm{II})$ ions were deeply trapped in the layer structure of TNTs. Thus, under the synergistic effects of physical and chemical adsorption, the hydrogel revealed excellent adsorption properties for heavy metal ions. Similar ion-exchange mechanisms have been found for the removal of dyes from aqueous solutions [127-129].

\subsection{Hydrogen Bonding}

H-bonding is a distinct form of dipole-dipole interaction that results from the electrostatic attractive force between a positively charged $\mathrm{H}$-atom and a more electronegative atom (i.e., N, O, F, etc.) or group, which are covalently bonded [130]. During the treatment of dye-containing wastewater, functional groups having oxygen (i.e., $-\mathrm{COOH},-\mathrm{OH}$ ) in the adsorbent molecules participate in H-bonding with pollutants (dyes) [131,132]. The adsorption of $\mathrm{MB}$ on a $\mathrm{CBH}$ (synthesized by modification of cellulose and acrylic acid) showed such interaction between electronegative $\mathrm{N}$-atom in $\mathrm{MB}$ structure and $\mathrm{H}$ atom in - $\mathrm{COOH}$ and -OH groups of HG (Figure 4) [133]. Recently, Sekine et al. [70] developed eco-friendly CMC nanofiber HGs, which were used to remove numerous chemical dyes through hydrogen bonding, electrostatic interactions, and hydrophobic interactions between the functional groups of dye and adsorbent molecules. Lie et al. [46] extensively explained the H-bonding interactions between the sulfur (S) atoms in both anionic (Acid Blue 93) and cationic (Methylene Blue) dyes and the $\mathrm{H}$ atoms in a $\mathrm{CBH}$ material along with the graphical presentation.

\subsection{Hydrophobic Interactions}

Hydrophobic interaction defines the interaction between hydrophobes and water molecules. Hydrophobes are non-polar compounds, which are composed of long chains of carbon that cannot interact with water molecules due to weak van der Waals attractive forces [134]. In addition, low water-soluble elements show a high tendency to be attracted to hydrophobes. Therefore, during wastewater treatment, hydrophobic interactions are formed to remove non-polar pollutants (i.e., pigments, disperse dyes, organic compounds, etc.) from aqueous solution (Figure 4) [135]. Li et al. [136] demonstrated both electrostatic and hydrophobic interactions between $\mathrm{MB}$ dye and functional groups $(-\mathrm{SH}$ and $-\mathrm{OH})$ present in thiol-modified CMC/L-cysteine HG. Hydrophobic interactions in CBHs offer extensive opportunities in HG engineering because of their roles in enriching mechanical properties [137,138]. Furthermore, the domain of hydrophobes provides a physical crosslinking point with optimal mechanical stiffness during the initiation of chemical reactions. The reaction continues with the formation of interactions between crosslinking points 
and other polymeric chains until macromolecular three-dimensional polymer networks are formed [139]. Lazzari et al. [140] recently showed that hydrophobic interaction is one of the main driving forces to adsorb insoluble organic pollutants into cellulose cryogels. However, $\mathrm{CBH}$ is often modified with both hydrophilic and hydrophobic functional groups to remove pollutants from aqueous solutions. The hydrophilic part of functional groups attracts soluble ionic pollutants through either electrostatic, H-bonding, and/or ion-exchange interactions, while the hydrophobic part contributes to the adsorption of water-insoluble contaminants [141,142].

\subsection{Coordination Interactions}

The coordination interaction refers to a covalent bond wherein both electrons are shared by a single atom. In the removal of cations (heavy metal ions and/or cationic dyes) from wastewater through a coordination mechanism, cations attract atoms in functional groups that have lone pair electrons (i.e., $\mathrm{O}$ and $\mathrm{N}$ ) in outer orbitals, resulting in the adsorption of cations on the adsorbate surface. Coordination interactions can also happen along with other interactions including ion-exchange, electrostatic interactions (Table 3). For example, at low $\mathrm{pH}, \mathrm{H}^{+}$ions from the adsorbent surface have been replaced with metal ions present in the solution, and these metal ions have a high affinity to negative electrons. Typically, different metal ions as well as $\mathrm{N}$ and $\mathrm{O}$ atoms in dye molecules are adsorbed on ion-exchanged functional groups (i.e., $-\mathrm{OH}$ ) via coordination bonds (Figure 4). One such experiment was recently conducted by Jayabrata Maity and Samit Kumar Ray (2017), where they observed the combined effects of coordination and electrostatic interactions during the removal of $\mathrm{Cu}^{2+}$ using sugar cane bagasse cellulose and gelatin-based composite hydrogels. $\mathrm{Cu}^{2+}$ ions formed coordination bonds with $\mathrm{N}$ or $\mathrm{O}$ atoms, which were sourced from $-\mathrm{NH}_{2}$ and $-\mathrm{OH}$ functional groups, respectively [143]. Tang et al. [54] also observed coordination interactions between metal ions and the $\mathrm{O}$ atoms (from - $\mathrm{OH}$ group) during the removal of $\mathrm{Hg}^{2+}, \mathrm{Pb}^{2+}$, and $\mathrm{Cu}^{2+}$ using chitin/cellulose composite (3:1) adsorbent. The adsorption mechanism of chitosan/cellulose composite adsorbent for the removal of Congo Red (CR) dye revealed electron sharing (coordination interaction) and transfer (electrostatic adsorption) between the adsorbent and adsorbate molecules [55]. 
Table 3. Proposed removal mechanism of contaminants by CBHs.

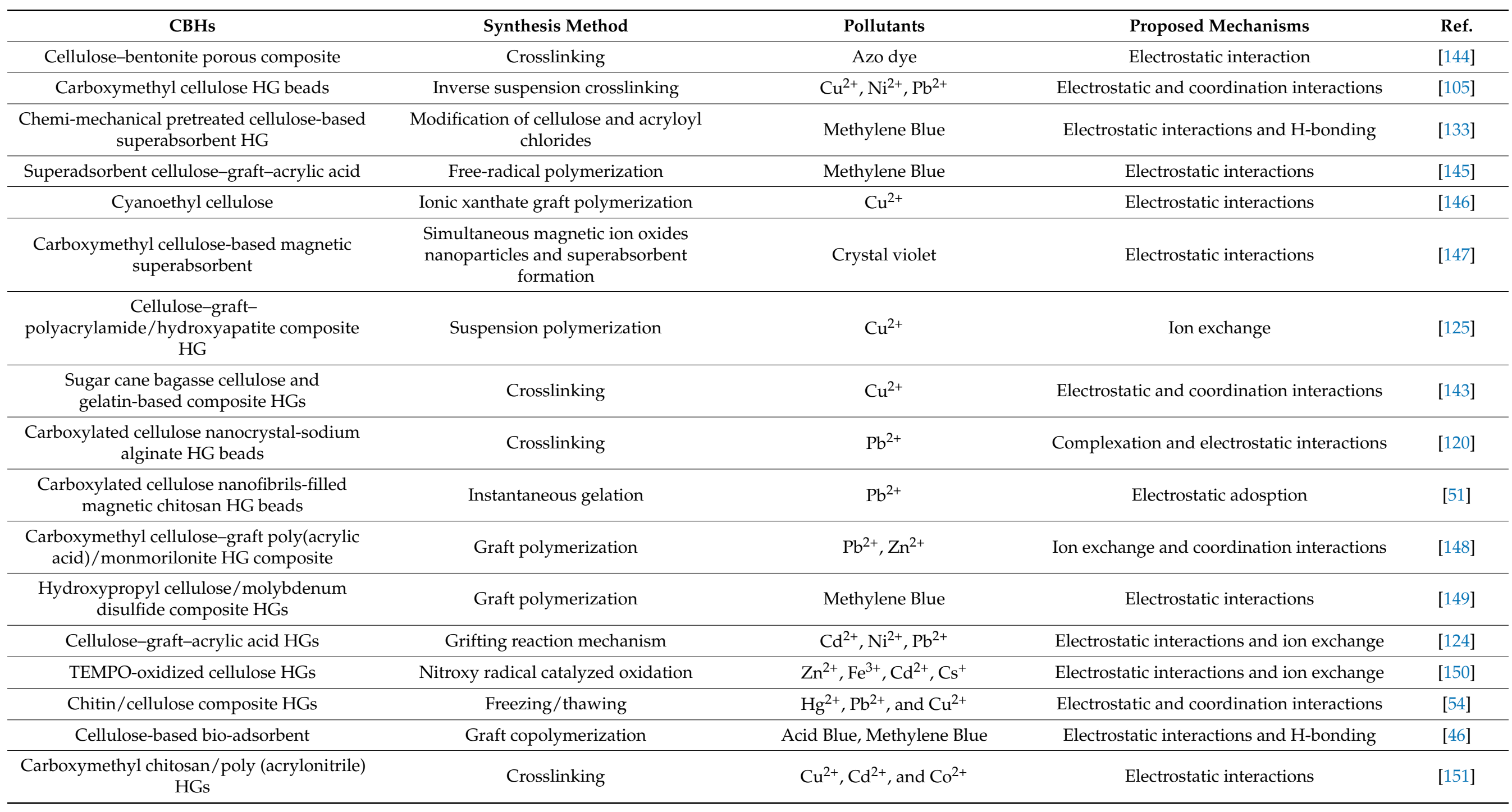


Table 3. Cont

\begin{tabular}{|c|c|c|c|c|}
\hline CBHs & Synthesis Method & Pollutants & Proposed Mechanisms & Ref. \\
\hline Chitogen/Cellulose HGs & Freeze-dried & Congo Red & Electrostatic and coordination interactions & {$[55,152]$} \\
\hline $\begin{array}{c}\text { Carboxymethyl cellulose structured } \\
\text { nano-adsorbent }\end{array}$ & Sol-gel method & Methyl Violet & Electrostatic and $\pi-\pi$ interactions & [153] \\
\hline Nanocomposite HG & Graft polymerization & Crystal Violet & Electrostatic interactions, H-bonding & [154] \\
\hline CMC-acrylamide-graphene oxide HGs & Radical polymerization & Acid Blue 133 & Electrostatic interactions & [81] \\
\hline $\begin{array}{l}\text { Lignocellulose-g-poly(acrylic } \\
\text { acid)/montmorillonite 3D crosslinked } \\
\text { polymeric netwrok HGs }\end{array}$ & Copolymerization & Methylene Blue & Electrostatic interactions & [155] \\
\hline Carboxymethyl Cellulose gel & $\gamma$-irradiation & $\mathrm{Cu}^{2+}$ & Chelation (coordination interactions) & [53] \\
\hline CMC-acrylic acid adsorbent & Graft polymerization & $\begin{array}{l}\text { Methyl Orange, Disperse Blue } \\
\text { 2BLN, and Malachite Green } \\
\text { Chloride }\end{array}$ & Electrostaic interactions & [152] \\
\hline $\begin{array}{l}\text { CMC /2-acrylamido-2-methyl propane } \\
\text { sulfonic acid HGs }\end{array}$ & Copolymerization and crosslinking & $\mathrm{Co}^{2+}, \mathrm{Cu}^{2+}, \mathrm{Mn}^{2+}, \mathrm{Fe}^{3+}$ & Electrostatic and chelating interactions & [156] \\
\hline
\end{tabular}




\section{6. $\pi-\pi$ Interactions}

$\pi-\pi$ interaction is a non-covalent interaction between adsorbent and adsorbate molecules in an aqueous solution. Numerous chemical properties, such as chemical bonding, boiling points, molecular and biomolecular crystallography, the structure of $\pi$-adjacent molecules, etc. are widely affected by $\pi-\pi$ interactions [157]. In typical $\pi-\pi$ interaction, at least one of the molecules contains a $\pi$ electron-rich or a deficient group in the structure of benzene or other aromatic rings that causes interactions in an aqueous medium. The $\pi-\pi$ interaction significantly depends on the functional groups present on both the adsorbate and adsorbent surface and medium of the solution $(\mathrm{pH})$ [158]. Based on these functional groups coupled with the $\mathrm{pH}$ of the solution, the adsorbate and adsorbent molecules act as an electron-donor or electron-acceptor, resulting in forming various $\pi-\pi$ interactions (electron-donor-acceptor, electron-acceptor-acceptor, and electron-donor-donor) [159]. These types of interactions are usually found during the adsorption of organic pollutants and dyes onto graphene-, graphene oxide-, or carbon-based HGs. Sharma et al. [153] attained an adsorption capacity of $96.43 \mathrm{mg} / \mathrm{g}$ for Methyl Violet (dye) using a CMC-structured nano adsorbent. $\pi-\pi$ stacking with electrostatic interactions were reported as the potential causes for such high adsorption capabilities where contaminants donated $\pi$-electrons to the adsorbent molecules. Chen et al. [160] also reported that $\pi-\pi$ stacking is the primary driving force in the removal of heavy metal ions $\left(\mathrm{Cu}^{2+}, \mathrm{Zn}^{2+}, \mathrm{Fe}^{3+}\right.$, and $\left.\mathrm{Pb}^{2+}\right)$ from wastewater using $\mathrm{GO} /$ cellulose $\mathrm{HG}$. The $-\mathrm{COOH}$ and $-\mathrm{OH}$ functional groups on the adsorbent surface (introduced from GO) made $\pi-\pi$ interactions with adjacent metal ions. The role of GO in the HG was to enhance mechanical strength as well as the adsorption capability of porous $\mathrm{GO} /$ cellulose HGs. Another type of GO/cellulose HG with high mechanical and thermal stabilities was prepared to remove contaminants from waste solution [161]. In another study, Yan et al. [162] prepared a self-healing HG with great mechanical strength based on cellulose-derived co-polydopamine@Pd nanoparticles for the reduction of contaminant dye in wastewater. They attained $>95 \%$ removal of both anionic and cationic dyes from wastewater through $\pi-\pi$ interactions, hydrogen bonding, and coordination interactions without a significant decrease in the performance or integrity of the HG structure, even though the water molecules continuously weaken to van der Waals interaction to decrease the mechanical properties and stability of HG [163-165]. For carboxymethyl cellulose sodium (CMCNa)/graphene oxide (GO) hydrogel microparticles, Liu et al. [166] suggested that the adsorption mechanism for dyes were due to both electrostatic and $\pi-\pi$ interactions, while those for heavy metals were the synergistic effect of electrostatic interactions, surface complexation, and ion exchange.

\section{Factors Affecting the Adsorption Capacity of CBHs}

\subsection{Crosslink Density}

Crosslink density refers to the density of chains or segments that attach two or more parts of the polymer network, instead of the density of crosslink junctures. The adsorption capacity of CBHs is highly affected by the crosslink density of polymeric segments [167-169]. The highest adsorption capacities for CBHs are typically obtained for the lowest crosslink density and vice versa [168]. However, there is a minimum value of crosslink density, which is necessary to avoid mechanical failure or outright dissolution of the adsorbent materials [170]. At the point of the lowest crosslinking density, the molecular weight of the HGs is preferred to be high to ensure that most of the polymeric chains are bound by a minimum of one covalent bond to the rest of the material. Studies showed that higher molecular weight CMC HGs have a higher internal volume in the polymeric chain that causes an increase in the adsorption capacity of the HGs [169]. The surface and cross-section porous structure of a $\mathrm{CBH}$ is shown as a function of crosslinking density in critical content. The crosslink density of dual crosslinked hydrogel (DCH) was higher than single crosslinked hydrogel $(\mathrm{SCH})$ because of a decrease in water content during crosslinking. Due to the increase of crosslink density in the polymeric network, the adjacent 
chains of HG materials came closer, resulting in a significant decrease of the surface and cross-section porous structure of DCH (Figure 5) [171].

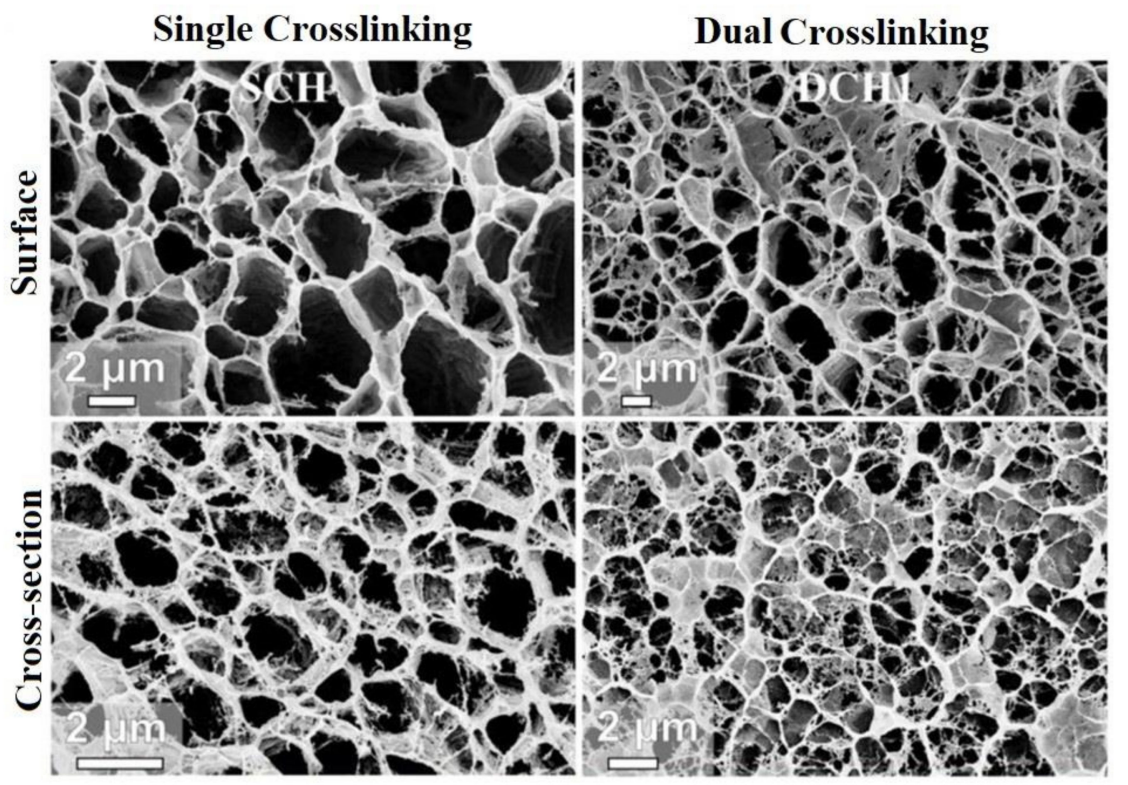

Figure 5. Morphology of single crosslinked hydrogel (HG) (SCH) and dual crosslinked HG (DCH) specimens: Surface and cross-sectional SEM images of SCH and DCH [171].

\subsection{Initial Concentration of Pollutant (ICP)}

The amount of pollutants adsorbed on the adsorbent surface is highly dependent on the initial concentration of pollutant (ICP). In a fixed solution volume and adsorbent mass, the number of adsorbate molecules is proliferated when ICP in wastewater is increased [172]. Consequently, more adsorbate molecules bind to the active sites of the adsorbent, thus accelerating the diffusion of dyes or heavy metals onto the adsorbent sites due to the increase in driving force of concentration gradient, resulting in higher adsorption capacities [9]. However, a decline of adsorption efficiency due to higher pollutant concentration was reported in some recent works $[173,174]$. In the typical adsorption process, adsorption capacity is sharply increased until the plateau state. Afterward, a further increase in ICP does not improve the adsorption process, resulting in a decrease in adsorption capacity [175]. The following explanation was made in most of the current works: at low pollutant concentration, the ratio of an initial number of moles of pollutant ions to the accessible sites of $\mathrm{CBH}$ is large, which causes higher adsorption capacity. On the other hand, at higher pollutant concentrations, the number of available adsorbent sites becomes fewer, resulting in a decrease in pollutant removal efficiency [160,174]. Wang et al. [155] studied the influences of the initial concentration of MB dye on adsorption capacity utilizing MB concentration between 1800 and $2700 \mathrm{mg} / \mathrm{L}$. The adsorption capacity was linearly increased with initial dye concentration until a plateau was achieved at $2500 \mathrm{mg} / \mathrm{L}$. At a concentration above $2500 \mathrm{mg} / \mathrm{L}$, the adsorption capacity started to decrease with increasing concentration. Recent studies on other $\mathrm{CBHs}$ for the removal of dyes and heavy metals also reported a similar trend of adsorption capacity with respect to ICP. The adsorption capacities of different CBHs as a function of initial concentration are summarized in Table 4. 
Table 4. Effects of initial pollutant concentration on adsorption capacities of CBHs.

\begin{tabular}{|c|c|c|c|c|}
\hline Materials & Dye/Metal & Initial Concentration (mg/L) & Adsorption Capacity (mg/g) & Ref. \\
\hline \multirow{4}{*}{ Cellulose-based porous adsorbent } & \multirow{4}{*}{ Methylene Blue } & 3000 & 1505.2 & \multirow{4}{*}{ [175] } \\
\hline & & 2500 & 1471.5 & \\
\hline & & 1500 & 1175.4 & \\
\hline & & 500 & 237.7 & \\
\hline \multirow{3}{*}{$\begin{array}{l}\text { Lignocellulose-based nanocomposite } \\
\text { hydrogel }\end{array}$} & \multirow{3}{*}{ Methylene Blue } & 2500 & 1975 & \multirow{3}{*}{ [155] } \\
\hline & & 2200 & 1875 & \\
\hline & & 1800 & 1710 & \\
\hline \multirow{3}{*}{ Carboxymethyl-based cellulose } & \multirow{3}{*}{ Methyl Orange } & 1500 & 1825 & \multirow{3}{*}{ [176] } \\
\hline & & 1000 & 1650 & \\
\hline & & 500 & 950 & \\
\hline Chitosan/cellulose hydrogels & Congo Red & 500 & 165 & [55] \\
\hline Pineapple peel CBH & Methylene Blue & 200 & 150 & {$[55,177]$} \\
\hline \multirow{12}{*}{ Cellulose-based adsorbent } & \multirow{4}{*}{$\mathrm{Cd}^{2+}$} & 600 & 350 & \multirow{12}{*}{ [124] } \\
\hline & & 1000 & 460 & \\
\hline & & 1600 & 530 & \\
\hline & & 2000 & 540 & \\
\hline & & 600 & 420 & \\
\hline & $\mathrm{Ph}^{2+}$ & 1000 & 630 & \\
\hline & $\mathrm{Pb}^{-1}$ & 1600 & 780 & \\
\hline & & 2000 & 810 & \\
\hline & \multirow{4}{*}{$\mathrm{Ni}^{2+}$} & 600 & 200 & \\
\hline & & 1000 & 320 & \\
\hline & & 1600 & 350 & \\
\hline & & 2000 & 360 & \\
\hline \multirow{4}{*}{ Carboxymethyl Cellulose } & & 200 & 90 & \multirow{4}{*}{ [148] } \\
\hline & $\mathrm{Zn}^{2+}$ & 500 & 170 & \\
\hline & \multirow{2}{*}{$\mathrm{Pb}^{2+}$} & 200 & 65 & \\
\hline & & 500 & 110 & \\
\hline
\end{tabular}

\section{3. $\mathrm{pH}$ at the Point of Zero Charge}

The $\mathrm{pH}$ at the point of zero charge $\left(\mathrm{pH}_{\mathrm{PZC}}\right)$ is a critical parameter for the adsorption process that can change the chelating ability of adsorbents by affecting their swelling ability and interactions between adsorbents and ions [156]. When the $\mathrm{pH}<\mathrm{pH}_{\mathrm{PZC}}$, the adsorbent surface is positively charged because of an increase of $\mathrm{H}^{+}$concentration in the aqueous solution (protonation). Hence, strong electrostatic interactions occur between the positively charged adsorbent surface and anions. Conversely, the aqueous solution is deprotonated at $\mathrm{pH}>\mathrm{pH}_{\mathrm{PZC}}$, creating a negatively charged surface that interacts with cations [117-119]. The protonation and deprotonation mainly occur at different functional groups, such as carboxylic [105] or amine [174,178], and the precipitation of ions in HGs. Typically, the adsorption capacity of $\mathrm{CBHs}$ for heavy metal ions is higher at the basic $\mathrm{pH}$ of the solution; in fact, there is a range of $\mathrm{pH}$ values for each metal ion wherein the maximum adsorption occurs. However, at $\mathrm{pH}>7.0$, metal ions interact with excess $\mathrm{OH}^{-}$in aqueous solution and precipitate as metal hydroxides form, thus impeding the adsorption process and reduce the adsorption capacity of HGs. The typical $\mathrm{pH}$ used for optimum metal adsorption on CBH materials is about 5.0-6.0 [160,178,179]. Recently, Amr El-Hag Ali [156] investigated the adsorptive nature of $\mathrm{CMC}$ as a function of solution $\mathrm{pH}$ for the removal of heavy metals such as $\mathrm{Co}^{2+}, \mathrm{Cu}^{2+}, \mathrm{Fe}^{3+}$, and $\mathrm{Mn}^{2+}$ from wastewater. Results showed that the adsorption capacity of CMC HGs increases at higher $\mathrm{pH}$ values. Excessive $\mathrm{H}^{+}$at extremely low $\mathrm{pH}$ values compete with metal ions to cohere active sites of the $\mathrm{CMC}$, causing a lower uptake of metal ions. The same adsorption protocol is applicable to eliminate dyes from wastewater using CBHs. For instance, the maximum adsorption capacity of a novel $\mathrm{CBH}$ for the removal of Congo Red $(\mathrm{CR})$, an anionic dye, was obtained at $\mathrm{pH} \approx 4.0$, and the adsorption capacity was declined with increasing $\mathrm{pH}$ values. At higher $\mathrm{pH}$, the excess $\mathrm{OH}^{-}$covers active sites of adsorbent molecules that limit the adsorption of CR dye molecules [82]. 
Conversely, cationic dyes are adsorbed on the adsorbent surface at higher $\mathrm{pH}$ values such as metal ions [116]. Table 5 includes some examples of $\mathrm{pH}$ values required to maximize the adsorption capacity of various CBHs.

Table 5. Effects of $\mathrm{pH}$ on adsorption capacities of different CBHs.

\begin{tabular}{cccc}
\hline Materials & Dye/Metal & pH for Max. Adsorption & Ref. \\
\hline Porous cellulose-based bio-adsorbent & Methylene Blue (cationic dye) & 9.0 & {$[46]$} \\
\hline Carboxymethyl cellulose & $\mathrm{Cd}^{2+}, \mathrm{Pb}^{2+}$ & 4.0 & 3.0 \\
\hline Cellulose-graft-acrylic acid HGs & $\mathrm{Cd}^{2+}, \mathrm{Pb}^{2+}, \mathrm{Ni}^{2+}$ & 2.0 & {$[180]$} \\
\hline Amide-functionalized cellulose-based & Acid Black (anionic dye) & 2.0 & 7.0 \\
porous adsorbent & Acid Red (anionic dye) & $\mathrm{Cu}^{2+}$ & {$[181]$} \\
\hline
\end{tabular}

\subsection{Temperature}

The adsorption capacity of $\mathrm{CBHs}$ greatly depends on temperature since the kinetic of adsorbate molecules in the aqueous solution is significantly changed when the temperature is raised. In the endothermic adsorption process, the adsorption capacity of CBHs is increased with the increase of temperature, which is the opposite of exothermic adsorption $[100,182]$. Typically, the adsorption capacity of CBHs for the removal of dyes from an aqueous solution is proportionally increased with temperature $[46,183,184]$. According to Lin et al. [46], the mobility of dye molecules is notably increased at higher temperatures, providing a higher potential to enhance the interactions between dye molecules and the adsorbent surface. As a result, the dye desorption from the adsorbent surface is minimized, leading to a higher adsorption capacity. Additionally, a swelling effect within the $\mathrm{CBH}$ structure may initiate due to the increase of temperature, causing the further penetration of dyes onto the adsorbent surface [182]. However, the adsorption capacity becomes independent of temperature when equilibrium is achieved (Figure 6B; blue bar). Similar to non-CBH adsorbent (Figure $6 \mathrm{~A}$ ), the adsorption capacity of $\mathrm{CBH}$ adsorbent is slightly fallen with an additional increase of temperature after equilibrium (Figure 6B; red bar) [184]. When adsorption takes place at a temperature higher than equilibrium temperature, the desorption characteristics of the $\mathrm{CBH}$ molecules become dominant, owing to the excessive molecular motion that causes such a slight decrease of the adsorption capacity [46]. Furthermore, similar to adsorptive removal of dyes from wastewater, $\mathrm{CBHs}$ show higher adsorption capacity for the removal of metal ions through endothermic adsorption [185], while the adsorption capacity is significantly lower for exothermic adsorption [186].

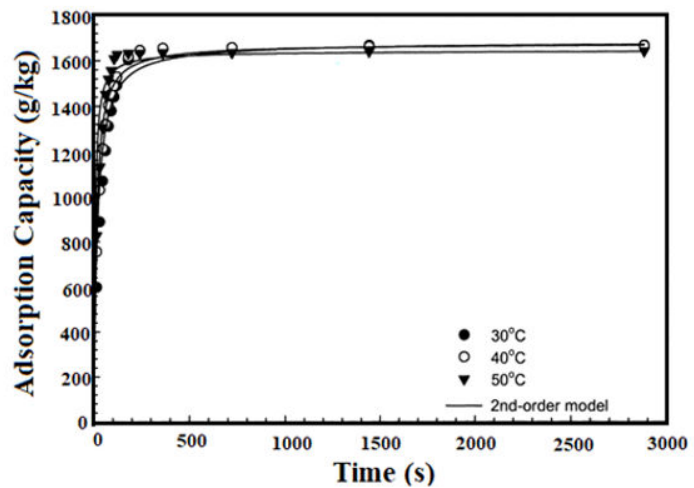

(A)

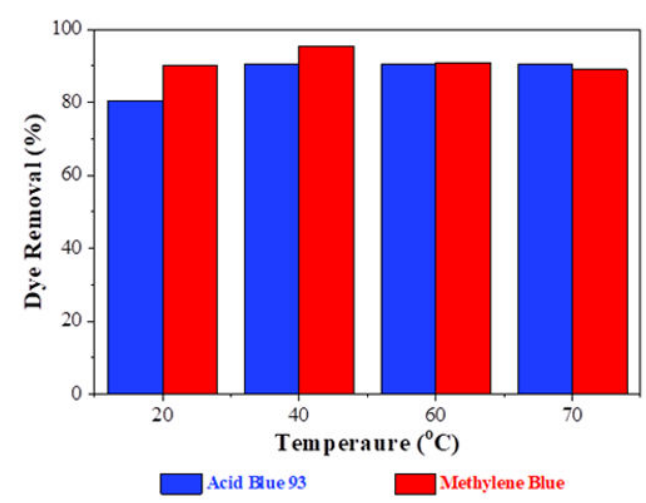

(B)

Figure 6. Effect of temperature on adsorption capacity: (A) adsorption kinetics of Reactive Red 189 dye on crosslinked chitosan; $\mathrm{pH}=3.0$, initial dye concentration $=3768 \mathrm{~g} / \mathrm{m}^{3}$, adsorbent size $=2.3-2.5 \mathrm{~nm}$, and crosslinking ratio $=0.2$ [184], (B) percent adsorption of Acid Blue and MB dyes on CBHs [46]. 


\subsection{Ionic Strength}

The ionic strength of an aqueous solution refers to the concentration of ions present in that solution. The ions in the solution are usually formed by dissociation of salts when dissolved in aqueous medium. In other words, the more salts in a solution, the higher the ionic strength of that solution [187]. Typically, industrial wastewater contains a wide variety of salts, such as $\mathrm{NaCl}, \mathrm{KCl}, \mathrm{NH}_{4} \mathrm{Cl}, \mathrm{CaCl}_{2}, \mathrm{MgSO}_{4}, \mathrm{AlCl}_{3}$, etc. along with other organic and inorganic pollutants, and these salts show strong influences on the adsorption capacity of CBHs during wastewater treatment [188]. The relationship between ionic strength and adsorption capacity is mostly studied for dye removal from aqueous solutions. Liu et al. [46] demonstrated the effects of ionic strength on the dye removal efficiency of acrylic acid and acrylamide grafted $\mathrm{CBH}$, where they used a different amount of $\mathrm{NaCl}$ salt to change the ionic strength of the solution. According to their study, the dye removal efficiency was decreased with increasing $\mathrm{NaCl}$ concentration, due to the competitive effect between the salt ions $\left(\mathrm{Na}^{+}\right.$and $\left.\mathrm{Cl}^{-}\right)$and the existing dyes with functional groups $\left(-\mathrm{COO}^{-},-\mathrm{NH}_{3}{ }^{+}\right.$, and $\mathrm{OH}^{-}$) on the $\mathrm{CBH}$ surface. With the growth of $\mathrm{NaCl}$ concentration, the shielding effect of $\mathrm{Na}^{+}$and $\mathrm{Cl}^{-}$ions for the ionized dye molecules was improved, which causes the reduction of adsorption efficiency of adsorbents $[189,190]$. In addition to $\mathrm{NaCl}$, the absorbency of $\mathrm{CBH}$ was also decreased with a higher concentration of other salts, including $\mathrm{KCl}, \mathrm{NH}_{4} \mathrm{Cl}, \mathrm{CaCl}_{2}$, and $\mathrm{AlCl}_{3}$. When compared among these salts, the adsorption capacity of $\mathrm{CBH}$ in the existence of monovalent cations reduces in the following order: $\mathrm{NH}^{4+}>$ $\mathrm{K}^{+}>\mathrm{Na}^{+}$. However, when compared based on ion valance, the highest declination of the swelling capacity of $\mathrm{CBH}$ was observed in the presence of trivalent cations with the following descending order: trivalent $>$ divalent $>$ monovalent cations [191].

\subsection{Coexistence of Ions}

The coexistence of various ions in the aqueous solution has mixed impacts on the adsorption efficiency of $\mathrm{HG}$ for each ion species. When multiple ions present in the solution, some of the ions either decrease the adsorption of others due to competition or collectively increase the adsorption through cosorption [192,193]. Antic et al. [193] investigated the sorption of $\mathrm{Pb}^{2+}$ in the presence of other ions, including $\mathrm{Ni}^{2+}, \mathrm{Cd}^{2+}, \mathrm{Cu}^{2+}, \mathrm{Zn}^{2+}$, and $\mathrm{Co}^{2+}$. In the binary system, the adsorption of $\mathrm{Pb}^{2+}$ was decreased by $5.27 \%$ due to competition, and it further decreased to $11.1 \%$ when the tertiary system was used. Furthermore, the existence of interference ions such as $\mathrm{K}^{+}, \mathrm{Na}^{+}, \mathrm{Mg}^{2+}$, and $\mathrm{Ca}^{2+}$ in the solution causes competition with heavy metal ions, such as $\mathrm{Cd}^{2+}, \mathrm{Cu}^{2+}$, and $\mathrm{Pb}^{2+}$ around the same surface of the adsorbent molecules, impeding the adsorption of heavy metals [194]. Sharing the same binding sites of HGs by existing ions in the solution is another potential cause for such low adsorption of heavy metals [192,195].

Moreover, the functional groups (i.e., $-\mathrm{COOH},-\mathrm{NH}_{2}$, etc.) entrapped in $\mathrm{HG}$ polymeric chains have shown selective adsorption for certain ions based on ion properties, including ionic radius, electronegativity, and ionization potential. For instance, $-\mathrm{COOH}$ in a nanocomposite $\mathrm{HG}$ has higher adsorption selectivity to $\mathrm{Pb}^{2+}$ compared to $\mathrm{Ni}^{2+}, \mathrm{Cd}^{2+}$, $\mathrm{Cu}^{2+}$, and $\mathrm{Zn}^{2+}$ due to the difference in the above ionic properties [196]. The metal ions show more propensity to HGs compared to other ions when the radius of metal ions is relatively higher. So, the bigger the ionic radius, the superior the binding capacity $[193,195]$. In addition to ionic radius, ion hydration radius also plays a vital role in metal ions removal efficiency and adsorption capacity. The literature showed that the change in adsorption capacity is very minimal for the ions with smaller hydration radius, even though the solution consisted of different interfering ions such as $\mathrm{Na}^{+}, \mathrm{Ca}^{2+}$, and $\mathrm{Ba}^{2+}$ [197].

In addition to that, the alternation of functional groups in the $\mathrm{CBH}$ structure has great influences on the adsorption selectivity of the adsorbent for specific metal ions. Amr El-Hag Ali investigated the simultaneous adsorption of $\mathrm{Mn}^{2+}, \mathrm{Co}^{2+}, \mathrm{Cu}^{2+}$, and $\mathrm{Fe}^{3+}$ on $\mathrm{CMC} / 2-$ acrylamido-2-methyl propane sulfonic acid (AMPS) HG derived by $\gamma$-radiations-induced copolymerization and crosslinking. He functionalized the adsorbent structure by altering the ceoncentratio of the AMPS. The uptake of metal ions for various AMPS concentration 
is summarized in Table 6 that revealed that the adsorption capacity of the CMC/AMPS adsorbent significantly increased with increasing concentration of the AMPS. One of the reasons for such behavior is solution $\mathrm{pH}$. Typically, the $\mathrm{pH}$ of the solution changes when the functional groups in CBH structure are altered [198]. The upsurge of AMPS concentration in the HG directs to the increment in the dissociated groups and subsequently risese the electrostatic repulsion, resulting in the expansion of the network structure.

Table 6. Effect of carboxymethyl cellulose (CMC)/2-acrylamido-2-methyl propane sulfonic acid (AMPS) composition on the adsorption of heavy metals.

\begin{tabular}{cccccc}
\hline \multirow{2}{*}{ AMPS Content (wt\%) } & \multirow{2}{*}{ Swelling (\%) } & \multicolumn{3}{c}{ Amount of Metal Ion Recovered (mg/g) } \\
\cline { 3 - 6 } & & $\mathbf{C o}^{2+}$ & $\mathbf{C u}^{2+}$ & $\mathbf{F e}^{3+}$ & $\mathbf{M n}^{\mathbf{2 +}}$ \\
\hline 10 & 581 & 16.3 & 27.4 & 25.3 & 7.1 \\
\hline 25 & 617 & 43.1 & 52.7 & 56.8 & 18.6 \\
\hline 50 & 690 & 60.6 & 75.3 & 80.4 & 46.8 \\
\hline
\end{tabular}

\section{Conclusions and Future Outlook}

Dyes and heavy metals released by various industries are among the most common pollutants of wastewaters, which have a detrimental effect on the environment including aquatic lives, human health, and the ecosystem. Therefore, the remediation of pollutants from the wastewater is imperative for a safer environment. The adsorption process involving different types of adsorbents is considered as an effective and efficient wastewater treatment method. However, most of the adsorbents used for the treatment purpose are synthetic and non-biodegradable, and management of the adsorbent after the treatment is another environmental concern that triggers the researchers to find and use a naturally derived and renewable source of materials as adsorbent. Cellulose-based hydrogels (CBHs) are ideal candidates meeting the requirement with some added benefits such as high removal efficiency, cost-effectiveness, and easy process. This review covers important aspects of wastewater treatment using $\mathrm{CBHs}$ such as the synthesis of $\mathrm{CBHs}$, adsorption mechanism, and parameters to optimize adsorption capacities, which have barely been covered in the literature. In addition, based on the limitations in the literature covered, the following scopes are recommended to address for future research consideration.

- Most of the literature covered treatments of lab-based wastewater containing a single pollutant, instead of real industrial wastewater. Some reports claimed that the presence of multiple ions in the wastewater may influence the adsorption of any specific ions [192,193]. Some wastewaters contain additives or other auxiliaries (such as salts, surfactants, etc. in textile wastewater) besides the target pollutant, which might have some potential impacts on the adsorption efficacy, and hence need to be explored. Therefore, extensive future work is needed to investigate the adsorption performance of $\mathrm{CBHs}$ in the real industrial wastewater system. The primary attempt could be the pilot-scale treatment of the industrial wastewater or at least simulated wastewater containing multiple pollutants that mimic real industrial wastewater.

- The greatest limitation perceived by the authors during the preparation of the paper is the lack of clarity and inadequate information on the adsorption mechanism. Moreover, the adsorption behavior of $\mathrm{CBH}$ for non-ionic pollutants such as non-ionic dyes, water-insoluble dyes (such as pigments, disperse dyes, vat dyes, sulfur dyes, etc.) have been overlooked in the literature. Consequently, more experimental and theoretical research is a pressing need to comprehend adsorption mechanisms that might potentially help unlock and identify the most effective mechanism.

- Many cellulose-based hydrogels lose their adsorption capacity after regeneration. Some reports revealed that the hydrogels retained the adsorption capacity only when regeneration is conducted with caustic soda. Moreover, modifications (both physical and chemical) and pretreatments of cellulose can enhance the adsorption capacity 
of the CBHs to some extent. Several chemical and physical networking approaches, such as modification with graphene oxide (GO), nanoparticles (NPs), carbon nanotubes (CNTs), and carbon quantum dots (CQDs), and blending with other suitable synthetic or natural polymers can be tested to enhance the gel characteristics as well as regeneration performances.

- The stable structure and effective swelling of $\mathrm{CBHs}$ are crucial for wastewater treatment especially at the condition of elevated temperature of the industrial waste stream. Some CBHs tend to weaken and lose their mechanical strength upon repeated swelling. A chemically crosslinked network often improves the stability and adsorption performance of the hydrogels. Moreover, the incorporation of magnetic particles, nanoparticles, and different chemical catalysts should be investigated to enhance the adsorption capacity and swelling properties of the CBHs. It is important to explore the scope of improving the mechanical durability of $\mathrm{CBHs}$ with increases in self-healing ability after a swollen state.

- The overall physiochemical composition and morphology of the CBHs mostly dictate their performance in the area of industrial wastewater treatment. A designed formulation and optimized synthesis conditions are critical parameters in designing a specific $\mathrm{CBH}$ overcoming the challenges and shortcomings such as low turnover number, lesser resistivity, and mechanical strength. In addition, issues in thermal stability, swelling ratio, and $\mathrm{pH}$ sensitivity still need to be addressed for its full-scale implementation.

Supplementary Materials: The following are available online at https:/ /www.mdpi.com/2310-2 861/7/1/30/s1, Table S1: Recent works on removal of heavy metals using CBHs, Table S2: Recent works on removal of dyes using CBHs.

Funding: This research received no external funding.

Conflicts of Interest: The authors declare no conflict of interest.

\section{References}

1. Rashid, T.U.; Kabir, S.M.F.; Biswas, M.C.; Bhuiyan, M.A.R. Sustainable Wastewater Treatment via Dye-Surfactant Interaction: A Critical Review. Ind. Eng. Chem. Res. 2020, 59, 9719-9745. [CrossRef]

2. Jørgensen, S.E. Freshwater Lakes. In Encyclopedia of Ecology; Jørgensen, S.E., Fath, B.D., Eds.; Academic Press: Oxford, UK, 2008; pp. 1686-1689. [CrossRef]

3. Cavin, L. 1-Freshwater Environments and Fishes. In Freshwater Fishes: 250 Million Years of Evolutionary History; Cavin, L., Ed.; Elsevier: Oxford, UK, 2017; pp. 1-14. [CrossRef]

4. Varghese, A.G.; Paul, S.A.; Latha, M.S. Remediation of heavy metals and dyes from wastewater using cellulose-based adsorbents. Environ. Chem Lett 2019, 17, 867-877. [CrossRef]

5. Rosegrant, M.W.; Cai, X. Water scarcity and food security: Alternative futures for the 21st century. Water Sci. Technol. 2001, 43, 61-70. [CrossRef] [PubMed]

6. Kabir, S.; Cueto, R.; Balamurugan, S.; Romeo, L.D.; Kuttruff, J.T.; Marx, B.D.; Negulescu, I.I. Removal of acid dyes from textile wastewaters using fish scales by absorption process. Clean Technol. 2019, 1, 21. [CrossRef]

7. Kabir, S.; Rashid, T.U.; Negulescu, I.I. Gelation of textile dye solution treated with fish scales. Gels 2019, 5, 37. [CrossRef] [PubMed]

8. Ugwu, E.I.; Agunwamba, J.C. A review on the applicability of activated carbon derived from plant biomass in adsorption of chromium, copper, and zinc from industrial wastewater. Environ. Monit Assess 2020, 192. [CrossRef] [PubMed]

9. Wong, S.; Ghafar, N.A.; Ngadi, N.; Razmi, F.A.; Inuwa, I.M.; Mat, R.; Amin, N.A.S. Effective removal of anionic textile dyes using adsorbent synthesized from coffee waste. Sci. Rep. 2020, 10, 2928. [CrossRef] [PubMed]

10. Natarajan, R.; Manivasagan, R. Effect of operating parameters on dye wastewater treatment using Prosopis cineraria and kinetic modeling. Environ. Eng. Res. 2020, 25, 788-793. [CrossRef]

11. Litefti, K.; Freire, M.S.; Stitou, M.; Gonzalez-Alvarez, J. Adsorption of an anionic dye (Congo red) from aqueous solutions by pine bark. Sci. Rep. 2019, 9. [CrossRef]

12. Khan, F.S.A.; Mubarak, N.M.; Tan, Y.H.; Karri, R.R.; Khalid, M.; Walvekar, R.; Abdullah, E.C.; Mazari, S.A.; Nizamuddin, S. Magnetic nanoparticles incorporation into different substrates for dyes and heavy metals removal-A Review. Environ. Sci Pollut. $R$ 2020. [CrossRef]

13. Fu, F.; Wang, Q. Removal of heavy metal ions from wastewaters: A review. J. Environ. Manag. 2011, 92, 407-418. [CrossRef] 
14. Paulino, A.T.; Minasse, F.A.S.; Guilherme, M.R.; Reis, A.V.; Muniz, E.C.; Nozaki, J. Novel adsorbent based on silkworm chrysalides for removal of heavy metals from wastewaters. J. Colloid Interface Sci. 2006, 301, 479-487. [CrossRef]

15. Borba, C.E.; Guirardello, R.; Silva, E.A.; Veit, M.T.; Tavares, C.R.G. Removal of nickel(II) ions from aqueous solution by biosorption in a fixed bed column: Experimental and theoretical breakthrough curves. Biochem. Eng. J. 2006, 30, 184-191. [CrossRef]

16. Zhou, Y.; Hu, X.; Zhang, M.; Zhuo, X.; Niu, J. Preparation and Characterization of Modified Cellulose for Adsorption of Cd(II), $\mathrm{Hg}(\mathrm{II})$, and Acid Fuchsin from Aqueous Solutions. Ind. Eng. Chem. Res. 2013, 52, 876-884. [CrossRef]

17. Srivastava, V.; Sharma, Y.C.; Sillanpää, M. Application of nano-magnesso ferrite (n-MgFe2O4) for the removal of Co2+ ions from synthetic wastewater: Kinetic, equilibrium and thermodynamic studies. Appl. Surf. Sci. 2015, 338, 42-54. [CrossRef]

18. Gupta, V.K.; Nayak, A.; Agarwal, S. Bioadsorbents for remediation of heavy metals: Current status and their future prospects. Environ. Eng. Res. 2015, 20,1-18. [CrossRef]

19. Saleh, T.A.; Gupta, V.K. Processing methods, characteristics and adsorption behavior of tire derived carbons: A review. Adv. Colloid Interface Sci. 2014, 211, 93-101. [CrossRef]

20. Chakravarty, S.; Mohanty, A.; Sudha, T.N.; Upadhyay, A.K.; Konar, J.; Sircar, J.K.; Madhukar, A.; Gupta, K.K. Removal of Pb(II) ions from aqueous solution by adsorption using bael leaves (Aegle marmelos). J. Hazard. Mater. 2010, 173, 502-509. [CrossRef]

21. Zou, C.; Jiang, W.; Liang, J.; Sun, X.; Guan, Y. Removal of Pb(II) from aqueous solutions by adsorption on magnetic bentonite. Environ. Sci Pollut. R 2018, 26, 1315-1322. [CrossRef]

22. Kul, A.R.; Koyuncu, H. Adsorption of $\mathrm{Pb}(\mathrm{II})$ ions from aqueous solution by native and activated bentonite: Kinetic, equilibrium and thermodynamic study. J. Hazard. Mater. 2010, 179, 332-339. [CrossRef]

23. Khezami, L.; Capart, R. Removal of chromium(VI) from aqueous solution by activated carbons: Kinetic and equilibrium studies. J. Hazard. Mater. 2005, 123, 223-231. [CrossRef]

24. Ballav, N.; Maity, A.; Mishra, S.B. High efficient removal of chromium(VI) using glycine doped polypyrrole adsorbent from aqueous solution. Chem. Eng. J. 2012, 198-199, 536-546. [CrossRef]

25. Chung, K.-T. The significance of azo-reduction in the mutagenesis and carcinogenesis of azo dyes. Mutat. Res. Rev. Genet. Toxicol. 1983, 114, 269-281. [CrossRef]

26. Commities, E.C.S. Opinion on Risk of Cancer Caused by Textiles and Leather Goods Coloured with Azo-Dyes. In In Proceedings of the 7th CSTEE plenary meeting, Brussels, Belgium, 18 January 1999.

27. Gita, S.; Hussan, A.; Choudhury, T. Impact of textile dyes waste on aquatic environments and its treatment. Environ. Ecol. 2017, $35,2349-2353$.

28. Hassaan, M.A.; El Nemr, A.; Madkour, F.F. Removal of Mordant Violet 40 Dye from wastewater using UV/O3 Advanced oxidation Processes. In Proceedings of the International Conference on Biotechnology and Environment, Organized by Alexandria University, Alexandria, Egypt, 1-3 November 2016.

29. Savin, I.-I.; Butnaru, R. Wastewater characteristics in textile finishing mills. Environ. Eng. Manag. J. (EEMJ) 2008, 7, 859-864. [CrossRef]

30. Hassaan, M.A.; El Nemr, A.; Madkour, F.F. Advanced oxidation processes of Mordant Violet 40 dye in freshwater and seawater. Egypt. J. Aquat. Res. 2017, 43, 1-9. [CrossRef]

31. Catanho, M.; Malpass, G.R.P.; Motheo, A.d.J. Avaliação dos tratamentos eletroquímico e fotoeletroquímico na degradação de corantes têxteis. Química Nova 2006, 29, 983-989. [CrossRef]

32. Hassaan, M. Advanced Oxidation Processes of Some Organic Pollutants in Fresh and Seawatwater. Ph.D. Thesis, Faculty of Science, Port Said University, Port Fuad, Egypt, December 2016.

33. Hassaan, M.A.; El Nemr, A. Health and environmental impacts of dyes: Mini review. Am. J. Environ. Sci. Eng. 2017, 1, 64-67.

34. Nguyen, T.A.; Juang, R.-S. Treatment of waters and wastewaters containing sulfur dyes: A review. Chem. Eng. J. 2013, 219, 109-117. [CrossRef]

35. Lellis, B.; Fávaro-Polonio, C.Z.; Pamphile, J.A.; Polonio, J.C. Effects of textile dyes on health and the environment and bioremediation potential of living organisms. Biotechnol. Res. Innov. 2019, 3, 275-290. [CrossRef]

36. Carneiro, P.A.; Umbuzeiro, G.A.; Oliveira, D.P.; Zanoni, M.V.B. Assessment of water contamination caused by a mutagenic textile effluent/dyehouse effluent bearing disperse dyes. J. Hazard. Mater. 2010, 174, 694-699. [CrossRef]

37. Fba, R.; Akter, M. Removal of Dyes Form Textile Wastewater by Adsorption using Shrimp Shell. Int. J. Waste Resour. 2016, 6. [CrossRef]

38. Cho, D.W.; Jeon, B.H.; Chon, C.M.; Schwartz, F.W.; Jeong, Y.; Song, H. Magnetic chitosan composite for adsorption of cationic and anionic dyes in aqueous solution. J. Ind. Eng. Chem. 2015, 28, 60-66. [CrossRef]

39. Fahim Bin Abdur Rahman, M.A.; Zainal Abedin, M. Dyes removal from textile wastewater using orange peels. Int. J. Sci. Technol. Res. 2013, 2, 47-50.

40. Namvari, M.; Namazi, H. Synthesis of magnetic citric-acid-functionalized graphene oxide and its application in the removal of methylene blue from contaminated water. Polym. Int. 2014, 63, 1881-1888. [CrossRef]

41. Liu, L.H.; Lin, Y.; Liu, Y.Y.; Zhu, H.; He, Q. Removal of Methylene Blue from Aqueous Solutions by Sewage Sludge Based Granular Activated Carbon: Adsorption Equilibrium, Kinetics, and Thermodynamics. J. Chem. Eng. Data 2013, 58, $2248-2253$. [CrossRef]

42. Vanamudan, A.; Bandwala, K.; Pamidimukkala, P. Adsorption property of Rhodamine 6G onto chitosan-g-(N-vinyl pyrrolidone)/montmorillonite composite. Int. J. Biol. Macromol. 2014, 69, 506-513. [CrossRef] 
43. Karimi, M.H.; Mandavinia, G.R.; Massoumi, B.; Baghban, A.; Saraei, M. Ionically crosslinked magnetic chitosan/kappacarrageenan bioadsorbents for removal of anionic eriochrome black-T. Int. J. Biol. Macromol. 2018, 113, 361-375. [CrossRef]

44. Ahmed, E.M. Hydrogel: Preparation, characterization, and applications: A review. J. Adv. Res. 2015, 6, 105-121. [CrossRef]

45. Peng, B.L.; Yao, Z.L.; Wang, X.C.; Crombeen, M.; Sweeney, D.G.; Tam, K.C. Cellulose-based materials in wastewater treatment of petroleum industry. Green Energy Environ. 2020, 5, 37-49. [CrossRef]

46. Liu, L.; Gao, Z.Y.; Su, X.P.; Chen, X.; Jiang, L.; Yao, J.M. Adsorption Removal of Dyes from Single and Binary Solutions Using a Cellulose-based Bioadsorbent. Acs Sustain. Chem. Eng. 2015, 3, 432-442. [CrossRef]

47. Malik, D.S.; Jain, C.K.; Yadav, A.K. Removal of heavy metals from emerging cellulosic low-cost adsorbents: A review. Appl. Water Sci. 2017, 7, 2113-2136. [CrossRef]

48. Kabir, S.F.; Sikdar, P.P.; Haque, B.; Bhuiyan, M.R.; Ali, A.; Islam, M. Cellulose-based hydrogel materials: Chemistry, properties and their prospective applications. Prog. Biomater. 2018, 7, 153-174. [CrossRef]

49. Khan, M.; Lo, I.M.C. A holistic review of hydrogel applications in the adsorptive removal of aqueous pollutants: Recent progress, challenges, and perspectives. Water Res. 2016, 106, 259-271. [CrossRef]

50. Mondal, M.I.H.; Haque, M.O. Cellulosic Hydrogels: A Greener Solution of Sustainability. In Cellulose-Based Superabsorbent Hydrogels; Mondal, M.I.H., Ed.; Springer International Publishing: Cham, Switzerland, 2019; pp. 3-35. [CrossRef]

51. Zhou, Y.M.; Fu, S.Y.; Zhang, L.L.; Zhan, H.Y.; Levit, M.V. Use of carboxylated cellulose nanofibrils-filled magnetic chitosan hydrogel beads as adsorbents for $\mathrm{Pb}(\mathrm{II})$. Carbohyd. Polym. 2014, 101, 75-82. [CrossRef]

52. Yang, S.P.; Fu, S.Y.; Liu, J.J.; Zhou, Y.M. Adsorption of Hydrogels Based on Cellulose for Cu(II) and Ni(II): Behaviors and Mechanisms. J. Macromol. Sci. B 2016, 55, 722-731. [CrossRef]

53. Hara, K.; Iida, A.; Yano, K.; Nishida, T. Metal ion absorption of carboxymethylcellulose gel formed by gamma-ray irradiation For the environmental purification. Colloid Surf. B 2004, 38, 227-230. [CrossRef]

54. Tang, H.; Chang, C.Y.; Zhang, L.N. Efficient adsorption of Hg2+ ions on chitin/cellulose composite membranes prepared via environmentally friendly pathway. Chem. Eng. J. 2011, 173, 689-697. [CrossRef]

55. Tu, H.; Yu, Y.; Chen, J.J.; Shi, X.W.; Zhou, J.L.; Deng, H.B.; Du, Y.M. Highly cost-effective and high-strength hydrogels as dye adsorbents from natural polymers: Chitosan and cellulose. Polym. Chem-Uk 2017, 8, 2913-2921. [CrossRef]

56. Yati, I.; Kizil, S.; Bulbul Sonmez, H. Cellulose-Based Hydrogels for Water Treatment. In Cellulose-Based Superabsorbent Hydrogels; Mondal, M.I.H., Ed.; Springer International Publishing: Cham, Switzerland, 2018; pp. 1-24. [CrossRef]

57. Shalla, A.H.; Yaseen, Z.; Bhat, M.A.; Rangreez, T.A.; Maswal, M. Recent review for removal of metal ions by hydrogels. Sep. Sci. Technol. 2019, 54, 89-100. [CrossRef]

58. Muya, F.N.; Sunday, C.E.; Baker, P.; Iwuoha, E. Environmental remediation of heavy metal ions from aqueous solution through hydrogel adsorption: A critical review. Water Sci. Technol. 2016, 73, 983-992. [CrossRef]

59. Van Tran, V.; Park, D.; Lee, Y.-C. Hydrogel applications for adsorption of contaminants in water and wastewater treatment. Environ. Sci. Pollut. R 2018, 25, 24569-24599. [CrossRef]

60. Sinha, V.; Chakma, S. Advances in the preparation of hydrogel for wastewater treatment: A concise review. J. Environ. Chem. Eng. 2019, 7, 103295. [CrossRef]

61. Pakdel, P.M.; Peighambardoust, S.J. A review on acrylic based hydrogels and their applications in wastewater treatment. J. Environ. Manag. 2018, 217, 123-143. [CrossRef]

62. Jing, G.; Wang, L.; Yu, H.; Amer, W.A.; Zhang, L. Recent progress on study of hybrid hydrogels for water treatment. Colloids Surf. A Physicochem. Eng. Asp. 2013, 416, 86-94. [CrossRef]

63. Pereira, A.G.; Rodrigues, F.H.; Paulino, A.T.; Martins, A.F.; Fajardo, A.R. Recent advances on composite hydrogels designed for the remediation of dye-contaminated water and wastewater: A review. J. Clean. Prod. 2020, 124703. [CrossRef]

64. Pang, Z.; Wang, P.; Dong, C. Ultrasonic pretreatment of cellulose in ionic liquid for efficient preparation of cellulose nanocrystals Cellulose 2018, 25, 7053-7064. [CrossRef]

65. Zhan, H.; Peng, N.; Lei, X.; Huang, Y.; Li, D.; Tao, R.; Chang, C. UV-induced self-cleanable TiO2/nanocellulose membrane for selective separation of oil/water emulsion. Carbohyd. Polym. 2018, 201, 464-470. [CrossRef]

66. Li, J.; Kang, L.; Wang, B.; Chen, K.; Tian, X.; Ge, Z.; Zeng, J.; Xu, J.; Gao, W. Controlled Release and Long-Term Antibacterial Activity of Dialdehyde Nanofibrillated Cellulose/Silver Nanoparticle Composites. Acs Sustain. Chem. Eng. 2018, 7, 1146-1158. [CrossRef]

67. Yang, X.; Bakaic, E.; Hoare, T.; Cranston, E.D. Injectable Polysaccharide Hydrogels Reinforced with Cellulose Nanocrystals: Morphology, Rheology, Degradation, and Cytotoxicity. Biomacromolecules 2013, 14, 4447-4455. [CrossRef]

68. Du, H.; Liu, W.; Zhang, M.; Si, C.; Zhang, X.; Li, B. Cellulose nanocrystals and cellulose nanofibrils based hydrogels for biomedical applications. Carbohyd. Polym. 2019, 209, 130-144. [CrossRef] [PubMed]

69. Pan, X.; Wang, Q.; He, P.; Liu, K.; Ni, Y.; Ouyang, X.; Chen, L.; Huang, L.; Wang, H.; Tan, Y. Mussel-Inspired Nanocomposite Hydrogel-Based Electrodes with Reusable and Injectable Properties for Human Electrophysiological Signals Detection. Acs Sustain. Chem. Eng. 2019, 7, 7918-7925. [CrossRef]

70. Benhalima, T.; Ferfera-Harrar, H. Eco-friendly porous carboxymethyl cellulose/dextran sulfate composite beads as reusable and efficient adsorbents of cationic dye methylene blue. Int. J. Biol. Macromol. 2019, 132, 126-141. [CrossRef] [PubMed]

71. Dai, L.; Cheng, T.; Xi, X.; Nie, S.; Ke, H.; Liu, Y.; Tong, S.; Chen, Z. A versatile TOCN/CGG self-assembling hydrogel for integrated wastewater treatment. Cellulose 2019, 27, 915-925. [CrossRef] 
72. Sharma, G.; Kumar, A.; Naushad, M.; García-Peñas, A.; Al-Muhtaseb, A.a.H.; Ghfar, A.A.; Sharma, V.; Ahamad, T.; Stadler, F.J. Fabrication and characterization of Gum arabic-cl-poly(acrylamide) nanohydrogel for effective adsorption of crystal violet dye. Carbohyd. Polym. 2018, 202, 444-453. [CrossRef] [PubMed]

73. Thakur, S.; Sharma, B.; Verma, A.; Chaudhary, J.; Tamulevicius, S.; Thakur, V.K. Recent approaches in guar gum hydrogel synthesis for water purification. Int. J. Polym. Anal. Charact. 2018, 23, 621-632. [CrossRef]

74. Chang, C.; Zhang, L. Cellulose-based hydrogels: Present status and application prospects. Carbohyd. Polym. 2011, 84, 40-53. [CrossRef]

75. Zainal, S.H.; Mohd, N.H.; Suhaili, N.; Anuar, F.H.; Lazim, A.M.; Othaman, R. Preparation of Cellulose-based Hydrogel: A Review. J. Mater. Res. Technol. 2020. [CrossRef]

76. Zhang, Y.S.; Khademhosseini, A. Advances in engineering hydrogels. Science 2017, 356, eaaf3627. [CrossRef]

77. Deng, J.; He, Q.; Wu, Z.; Yang, W. Using glycidyl methacrylate as cross-linking agent to prepare thermosensitive hydrogels by a novel one-step method. J. Polym. Sci. Part A Polym. Chem. 2008, 46, 2193-2201. [CrossRef]

78. Guo, K.; Chu, C.C. Synthesis and characterization of novel biodegradable unsaturated poly(ester amide)/poly(ethylene glycol) diacrylate hydrogels. J. Polym. Sci. Part A Polym. Chem. 2005, 43, 3932-3944. [CrossRef]

79. Hoffman, A.S. Hydrogels for biomedical applications. Adv. Drug Deliv. Rev. 2012, 64, 18-23. [CrossRef]

80. Kenawy, E.-R.; Kamoun, E.A.; Mohy Eldin, M.S.; El-Meligy, M.A. Physically crosslinked poly(vinyl alcohol)-hydroxyethyl starch blend hydrogel membranes: Synthesis and characterization for biomedical applications. Arab. J. Chem. 2014, 7, 372-380 [CrossRef]

81. Varaprasad, K.; Jayaramudu, T.; Sadiku, E.R. Removal of dye by carboxymethyl cellulose, acrylamide and graphene oxide via a free radical polymerization process. Carbohyd. Polym. 2017, 164, 186-194. [CrossRef]

82. Wang, Y.; Zhao, L.; Peng, H.; Wu, J.; Liu, Z.; Guo, X. Removal of Anionic Dyes from Aqueous Solutions by Cellulose-Based Adsorbents: Equilibrium, Kinetics, and Thermodynamics. J. Chem. Eng. Data 2016, 61, 3266-3276. [CrossRef]

83. Zhang, H.; Zhang, F.; Wu, J. Physically crosslinked hydrogels from polysaccharides prepared by freeze-thaw technique. React. Funct. Polym. 2013, 73, 923-928. [CrossRef]

84. Kassem, I.; Kassab, Z.; Khouloud, M.; Sehaqui, H.; Bouhfid, R.; Jacquemin, J.; Qaiss, A.E.K.; El Achaby, M. Phosphoric acidmediated green preparation of regenerated cellulose spheres and their use for all-cellulose cross-linked superabsorbent hydrogels. Int. J. Biol. Macromol. 2020, 162, 136-149. [CrossRef]

85. Catalina, M.; Cot, J.; Balu, A.M.; Serrano-Ruiz, J.C.; Luque, R. Tailor-made biopolymers from leather waste valorisation. Green Chem. 2012, 14, 308. [CrossRef]

86. Sun, X.; Peng, B.; Ji, Y.; Chen, J.; Li, D. Chitosan(chitin)/cellulose composite biosorbents prepared using ionic liquid for heavy metal ions adsorption. Aiche J. 2009, 55, 2062-2069. [CrossRef]

87. Wang, L.-Y.; Wang, M.-J. Removal of Heavy Metal Ions by Poly(vinyl alcohol) and Carboxymethyl Cellulose Composite Hydrogels Prepared by a Freeze-Thaw Method. Acs Sustain. Chem. Eng. 2016, 4, 2830-2837. [CrossRef]

88. Guan, Y.; Bian, J.; Peng, F.; Zhang, X.-M.; Sun, R.-C. High strength of hemicelluloses based hydrogels by freeze/thaw technique. Carbohyd. Polym. 2014, 101, 272-280. [CrossRef] [PubMed]

89. Millon, L.E.; Guhados, G.; Wan, W. Anisotropic polyvinyl alcohol-Bacterial cellulose nanocomposite for biomedical applications. J. Biomed. Mater. Res. Part B Appl. Biomater. 2008, 86B, 444-452. [CrossRef] [PubMed]

90. Qi, X.; Hu, X.; Wei, W.; Yu, H.; Li, J.; Zhang, J.; Dong, W. Investigation of Salecan/poly(vinyl alcohol) hydrogels prepared by freeze/thaw method. Carbohyd. Polym. 2015, 118, 60-69. [CrossRef] [PubMed]

91. Ali, A.; Ahmed, S. Recent Advances in Edible Polymer Based Hydrogels as a Sustainable Alternative to Conventional Polymers. J. Agric. Food Chem. 2018, 66, 6940-6967. [CrossRef]

92. Rajbhandary, A.; Nilsson, B.L. Self-Assembling Hydrogels. In GELS HANDBOOK: Fundamentals, Properties and Applications Volume 1: Fundamentals of Hydrogels; World Scientific Tuck Link: Singapore, 2016; pp. 219-250.

93. Feng, Y.; Gong, J.-L.; Zeng, G.-M.; Niu, Q.-Y.; Zhang, H.-Y.; Niu, C.-G.; Deng, J.-H.; Yan, M. Adsorption of Cd (II) and Zn (II) from aqueous solutions using magnetic hydroxyapatite nanoparticles as adsorbents. Chem. Eng. J. 2010, 162, 487-494. [CrossRef]

94. Ozay, O.; Ekici, S.; Baran, Y.; Aktas, N.; Sahiner, N. Removal of toxic metal ions with magnetic hydrogels. Water Res. 2009, 43, 4403-4411. [CrossRef]

95. Wang, J.; Wei, L.; Ma, Y.; Li, K.; Li, M.; Yu, Y.; Wang, L.; Qiu, H. Collagen/cellulose hydrogel beads reconstituted from ionic liquid solution for $\mathrm{Cu}(\mathrm{II})$ adsorption. Carbohyd. Polym. 2013, 98, 736-743. [CrossRef]

96. Elbedwehy, A.M.; Atta, A.M. Novel Superadsorbent Highly Porous Hydrogel Based on Arabic Gum and Acrylamide Grafts for Fast and Efficient Methylene Blue Removal. Polymers 2020, 12, 338. [CrossRef]

97. Klinpituksa, P.; Kosaiyakanon, P. Superabsorbent Polymer Based on Sodium Carboxymethyl Cellulose Grafted Polyacrylic Acid by Inverse Suspension Polymerization. Int. J. Polym. Sci. 2017, 2017, 3476921. [CrossRef]

98. Pedroso-Santana, S.; Fleitas-Salazar, N. Ionotropic gelation method in the synthesis of nanoparticles/microparticles for biomedical purposes. Polym. Int. 2020, 69, 443-447. [CrossRef]

99. Soleh Setiyawan, A.; Guerrero, R.; Acibar, C.; Alarde, C.M.; Maslog, J.; Pacilan, C.J.; Dwi Ariesyady, H.; Nastiti, A.; Roosmini, D.; Sonny Abfertiawan, M. Evaluation of $\mathrm{Pb}$ (II) Removal from Water Using Sodium Alginate/Hydroxypropyl Cellulose Beads. E3s Web Conf. 2020, 148, 02002. [CrossRef] 
100. Mohammed, N.; Grishkewich, N.; Berry, R.M.; Tam, K.C. Cellulose nanocrystal-alginate hydrogel beads as novel adsorbents for organic dyes in aqueous solutions. Cellulose 2015, 22, 3725-3738. [CrossRef]

101. Gennen, S.; Grignard, B.; Thomassin, J.-M.; Gilbert, B.; Vertruyen, B.; Jerome, C.; Detrembleur, C. Polyhydroxyurethane hydrogels: Synthesis and characterizations. Eur. Polym. J. 2016, 84, 849-862. [CrossRef]

102. Singh, A.; Narvi, S.; Dutta, P.; Pandey, N. External stimuli response on a novel chitosan hydrogel crosslinked with formaldehyde. Bull. Mater. Sci. 2006, 29, 233-238. [CrossRef]

103. Tian, Z.; Liu, W.; Li, G. The microstructure and stability of collagen hydrogel cross-linked by glutaraldehyde. Polym. Degrad. Stab. 2016, 130, 264-270. [CrossRef]

104. Voisin, H.; Bergström, L.; Liu, P.; Mathew, A.P. Nanocellulose-based materials for water purification. Nanomaterials $2017,7,57$. [CrossRef]

105. Yang, S.; Fu, S.; Liu, H.; Zhou, Y.; Li, X. Hydrogel beads based on carboxymethyl cellulose for removal heavy metal ions. J. Appl. Polym. Sci. 2011, 119, 1204-1210. [CrossRef]

106. Ge, H.; Huang, H.L.; Xu, M.; Chen, Q. Cellulose/poly(ethylene imine) composites as efficient and reusable adsorbents for heavy metal ions. Cellulose 2016, 23, 2527-2537. [CrossRef]

107. Tran, T.H.; Okabe, H.; Hidaka, Y.; Hara, K. Removal of metal ions from aqueous solutions using carboxymethyl cellulose/sodium styrene sulfonate gels prepared by radiation grafting. Carbohyd. Polym. 2017, 157, 335-343. [CrossRef]

108. Liu, X.; Xu, M.; An, B.; Wu, Z.; Yang, R.; Ma, C.; Huang, Q.; Li, W.; Li, J.; Liu, S. A facile hydrothermal method-fabricated robust and ultralight weight cellulose nanocrystal-based hydro/aerogels for metal ion removal. Environ. Sci Pollut $R$ 2019, 26, 25583-25595. [CrossRef]

109. Kadry, G.; Aboelmagd, E.I.; Ibrahim, M.M. Cellulosic-based hydrogel from biomass material for removal of metals from waste water. J. Macromol. Sci. A 2019, 56, 968-981. [CrossRef]

110. Ning, F.; Zhang, J.; Kang, M.X.; Ma, C.P.; Li, H.; Qiu, Z.M. Hydroxyethyl cellulose hydrogel modified with tannic acid as methylene blue adsorbent. J. Appl. Polym. Sci. 2021, 138. [CrossRef]

111. Yuan, H.M.; Peng, J.W.; Ren, T.T.; Luo, Q.Y.; Luo, Y.; Zhang, N.; Huang, Y.; Guo, X.; Wu, Y.Q. Novel fluorescent lignin-based hydrogel with cellulose nanofibers and carbon dots for highly efficient adsorption and detection of Cr(VI). Sci. Total Environ. 2021, 760. [CrossRef]

112. Fang, R.; He, W.; Xue, H.; Chen, W. Synthesis and characterization of a high-capacity cationic hydrogel adsorbent and its application in the removal of Acid Black 1 from aqueous solution. React. Funct. Polym. 2016, 102, 1-10. [CrossRef]

113. Mohammadi, Z.; Shangbin, S.; Berkland, C.; Liang, J.-T. Chelator-mimetic multi-functionalized hydrogel: Highly efficient and reusable sorbent for $\mathrm{Cd}, \mathrm{Pb}$, and As removal from waste water. Chem. Eng. J. 2017, 307, 496-502. [CrossRef]

114. Basri, S.N.; Zainuddin, N.; Hashim, K.; Yusof, N.A. Preparation and characterization of irradiated carboxymethyl sago starch-acid hydrogel and its application as metal scavenger in aqueous solution. Carbohyd. Polym. 2016, 138, 34-40. [CrossRef]

115. Deng, G.; Wong, W.-T.; Huang, M.; Wu, R.; Lai, W.-F. Chapter 8-Self-healing properties of hydrogels based on natural polymers. In Hydrogels Based on Natural Polymers; Chen, Y., Ed.; Elsevier: Amsterdam, The Netherlands, 2020; pp. 223-245. [CrossRef]

116. Li, S. Removal of crystal violet from aqueous solution by sorption into semi-interpenetrated networks hydrogels constituted of poly (acrylic acid-acrylamide-methacrylate) and amylose. Bioresour. Technol. 2010, 101, 2197-2202. [CrossRef]

117. Inbaraj, B.S.; Chiu, C.P.; Ho, G.H.; Yang, J.; Chen, B.H. Effects of temperature and pH on adsorption of basic brown 1 by the bacterial biopolymer poly( $\gamma$-glutamic acid). Bioresour. Technol. 2008, 99, 1026-1035. [CrossRef]

118. Pereira, R.C.; Anizelli, P.R.; Di Mauro, E.; Valezi, D.F.; da Costa, A.C.S.; Zaia, C.T.B.V.; Zaia, D.A.M. The effect of pH and ionic strength on the adsorption of glyphosate onto ferrihydrite. Geochem. Trans. 2019, 20, 3. [CrossRef] [PubMed]

119. Eskandari, S.; Dong, A.; De Castro, L.T.; Ab Rahman, F.B.; Lipp, J.; Blom, D.A.; Regalbuto, J.R. Pushing the limits of electrostatic adsorption: Charge enhanced dry impregnation of SBA-15. Catal. Today 2019, 338, 60-71. [CrossRef]

120. Hu, Z.-H.; Omer, A.M.; Ouyang, X.k.; Yu, D. Fabrication of carboxylated cellulose nanocrystal/sodium alginate hydrogel beads for adsorption of $\mathrm{Pb}$ (II) from aqueous solution. Int. J. Biol. Macromol. 2018, 108, 149-157. [CrossRef]

121. Jørgensen, S.E. Chapter 4-Adsorption and Ion Exchange. In Developments in Environmental Modelling; Jørgensen, S.E., Gromiec, M.J., Eds.; Elsevier: New York, NY, USA, 1989; Volume 14, pp. 65-81.

122. Wawrzkiewicz, M.; Hubicki, Z. Anion exchange resins as effective sorbents for removal of acid, reactive, and direct dyes from textile wastewaters. Ion Exch. Stud. Appl. 2015, 37-72. [CrossRef]

123. Kumar, P.; Mina, U. Fundamentals and Techniques of Biophysics and Molecular Biology; Pathfinder Publication: New Delhi, India, 2016.

124. Zhou, Y.M.; Zhang, L.L.; Fu, S.Y.; Zheng, L.M.; Zhan, H.Y. Adsorption behavior of Cd2+, Pb2+, and Ni 2+ from aquous solutions on cellulose-based hydrogels. BioResource 2012, 7, 2752-2765.

125. Saber-Samandari, S.; Saber-Samandari, S.; Gazi, M. Cellulose-graft-polyacrylamide/hydroxyapatite composite hydrogel with possible application in removal of Cu (II) ions. React. Funct. Polym. 2013, 73, 1523-1530. [CrossRef]

126. Xiong, Y.; Xu, L.L.; Jin, C.D.; Sun, Q.F. Cellulose hydrogel functionalized titanate microspheres with self-cleaning for efficient purification of heavy metals in oily wastewater. Cellulose 2020, 27, 7751-7763. [CrossRef]

127. Karcher, S.; Kornmüller, A.; Jekel, M. Anion exchange resins for removal of reactive dyes from textile wastewaters. Water Res. 2002, 36, 4717-4724. [CrossRef] 
128. Liu, C.H.; Wu, J.S.; Chiu, H.C.; Suen, S.Y.; Chu, K.H. Removal of anionic reactive dyes from water using anion exchange membranes as adsorbers. Water Res. 2007, 41, 1491-1500. [CrossRef]

129. Khan, M.I.; Akhtar, S.; Zafar, S.; Shaheen, A.; Khan, M.A.; Luque, R.; Rehman, A.U. Removal of Congo Red from Aqueous Solution by Anion Exchange Membrane (EBTAC): Adsorption Kinetics and Themodynamics. Materials 2015, 8, 4147-4161. [CrossRef]

130. Silverman, R.B.; Holladay, M.W. Chapter 3-Receptors. In The Organic Chemistry of Drug Design and Drug Action, 3rd ed.; Silverman, R.B., Holladay, M.W., Eds.; Academic Press: Boston, MA, USA, 2014; pp. 123-163. [CrossRef]

131. Zhu, Y.; Yi, B.; Yuan, Q.; Wu, Y.; Wang, M.; Yan, S. Removal of methylene blue from aqueous solution by cattle manure-derived low temperature biochar. Rsc Adv. 2018, 8, 19917-19929. [CrossRef]

132. Lafi, R.; Montasser, I.; Hafiane, A. Adsorption of congo red dye from aqueous solutions by prepared activated carbon with oxygen-containing functional groups and its regeneration. Adsorpt. Sci. Technol. 2018, 37, 160-181. [CrossRef]

133. Lin, Y.; Fang, G.G.; Deng, Y.J.; Shen, K.Z.; Wu, T.; Li, M. Highly Effective Removal of Methylene Blue Using a Chemi-Mechanical Pretreated Cellulose-based Superabsorbent Hydrogel. Bioresources 2018, 13, 8709-8722. [CrossRef]

134. Van Oss, C.J.; Good, R.J.; Chaudhury, M.K. The role of van der Waals forces and hydrogen bonds in "hydrophobic interactions" between biopolymers and low energy surfaces. J. Colloid Interface Sci. 1986, 111, 378-390. [CrossRef]

135. Lin, S.H. Adsorption of disperse dye by various adsorbents. J. Chem. Technol. Biotechnol. 1993, 58, 159-163. [CrossRef]

136. Hou, N.; Wang, R.; Wang, F.; Bai, J.; Jiao, T.; Bai, Z.; Zhang, L.; Zhou, J.; Peng, Q. Self-assembled hydrogels constructed via host-guest polymers with highly efficient dye removal capability for wastewater treatment. Colloids Surf. A Physicochem. Eng. Asp. 2019, 579, 123670. [CrossRef]

137. Yan, X.; Yang, J.; Chen, F.; Zhu, L.; Tang, Z.; Qin, G.; Chen, Q.; Chen, G. Mechanical properties of gelatin/polyacrylamide/graphene oxide nanocomposite double-network hydrogels. Compos. Sci. Technol. 2018, 163, 81-88. [CrossRef]

138. Chau, M.; De France, K.J.; Kopera, B.; Machado, V.R.; Rosenfeldt, S.; Reyes, L.; Chan, K.J.W.; Förster, S.; Cranston, E.D.; Hoare, T.; et al. Composite Hydrogels with Tunable Anisotropic Morphologies and Mechanical Properties. Chem. Mater. 2016, 28, 3406-3415. [CrossRef]

139. Jiang, H.; Duan, L.; Ren, X.; Gao, G. Hydrophobic association hydrogels with excellent mechanical and self-healing properties. Eur. Polym. J. 2019, 112, 660-669. [CrossRef]

140. Lazzari, L.K.; Zampieri, V.B.; Zanini, M.; Zattera, A.J.; Baldasso, C. Sorption capacity of hydrophobic cellulose cryogels silanized by two different methods. Cellulose 2017, 24, 3421-3431. [CrossRef]

141. Han, H.; Wei, W.; Jiang, Z.; Lu, J.; Zhu, J.; Xie, J. Removal of cationic dyes from aqueous solution by adsorption onto hydrophobic/hydrophilic silica aerogel. Colloids Surf. A Physicochem. Eng. Asp. 2016, 509, 539-549. [CrossRef]

142. Samaddar, P.; Kumar, S.; Kim, K.-H. Polymer Hydrogels and Their Applications Toward Sorptive Removal of Potential Aqueous Pollutants. Polym. Rev. 2019, 59, 418-464. [CrossRef]

143. Maity, J.; Ray, S.K. Removal of $\mathrm{Cu}$ (II) ion from water using sugar cane bagasse cellulose and gelatin based composite hydrogels. Int. J. Biol. Macromol. 2017, 97, 238-248. [CrossRef]

144. Santoso, S.P.; Kurniawan, A.; Soetaredjo, F.E.; Cheng, K.-C.; Putro, J.N.; Ismadji, S.; Ju, Y.-H. Eco-friendly cellulose-bentonite porous composite hydrogels for adsorptive removal of azo dye and soilless culture. Cellulose 2019, 26, 3339-3358. [CrossRef]

145. Zhou, Y.; Fu, S.; Liu, H.; Yang, S.; Zhan, H. Removal of methylene blue dyes from wastewater using cellulose-based superadsorbent hydrogels. Polym. Eng. Sci. 2011, 51, 2417-2424. [CrossRef]

146. Kamel, S.; Hassan, E.M.; El-Sakhawy, M. Preparation and application of acrylonitrile-grafted cyanoethyl cellulose for the removal of copper (II) ions. J. Appl. Polym. Sci. 2006, 100, 329-334. [CrossRef]

147. Hosseinzadeh, H.; Javadi, A. Fabrication and characterization of CMC-based magnetic superabsorbent hydrogel nanocomposites for crystal violet removal. Polym. Adv. Technol. 2016, 27, 1609-1616. [CrossRef]

148. Astrini, N.; Anah, L.; Haryadi, H.R. Adsorption of Heavy Metal Ion from Aqueous Solution by Using Cellulose Based Hydrogel Composite. Macromol. Symp. 2015, 353, 191-197. [CrossRef]

149. Chen, P.; Liu, X.; Jin, R.; Nie, W.; Zhou, Y. Dye adsorption and photo-induced recycling of hydroxypropyl cellulose/molybdenum disulfide composite hydrogels. Carbohyd. Polym. 2017, 167, 36-43. [CrossRef]

150. Isobe, N.; Chen, X.; Kim, U.-J.; Kimura, S.; Wada, M.; Saito, T.; Isogai, A. TEMPO-oxidized cellulose hydrogel as a high-capacity and reusable heavy metal ion adsorbent. J. Hazard. Mater. 2013, 260, 195-201. [CrossRef]

151. Mohamed, R.R.; Seoudi, R.S.; Sabaa, M.W. Synthesis and characterization of antibacterial semi-interpenetrating carboxymethyl chitosan/poly (acrylonitrile) hydrogels. Cellulose 2012, 19, 947-958. [CrossRef]

152. Zhang, G.; Yi, L.; Deng, H.; Sun, P. Dyes adsorption using a synthetic carboxymethyl cellulose-acrylic acid adsorbent. J. Environ. Sci. 2014, 26, 1203-1211. [CrossRef]

153. Sharma, G.; Kumar, A.; Sharma, S.; Naushad, M.; Ghfar, A.A.; Al-Muhtaseb, A.a.H.; Ahamad, T.; Sharma, N.; Stadler, F.J. Carboxymethyl cellulose structured nano-adsorbent for removal of methyl violet from aqueous solution: Isotherm and kinetic analyses. Cellulose 2020, 27, 3677-3691. [CrossRef]

154. Mahdavinia, G.R.; Hasanpour, J.; Rahmani, Z.; Karami, S.; Etemadi, H. Nanocomposite hydrogel from grafting of acrylamide onto HPMC using sodium montmorillonite nanoclay and removal of crystal violet dye. Cellulose 2013, 20, 2591-2604. [CrossRef]

155. Shi, Y.; Xue, Z.; Wang, X.; Wang, L.; Wang, A. Removal of methylene blue from aqueous solution by sorption on lignocelluloseg-poly (acrylic acid)/montmorillonite three-dimensional cross-linked polymeric network hydrogels. Polym. Bull. 2013, 70, 1163-1179. [CrossRef] 
156. El-Hag Ali, A. Removal of heavy metals from model wastewater by using carboxymehyl cellulose/2-acrylamido-2-methyl propane sulfonic acid hydrogels. J. Appl. Polym. Sci. 2012, 123, 763-769. [CrossRef]

157. Sherrill, C.D. Energy component analysis of $\pi$ interactions. Acc. Chem. Res. 2013, 46, 1020-1028. [CrossRef]

158. Alam, M.; Hossain, M.; Hossain, D.; Johir, M.A.H.; Hossen, J.; Rahman, M.S.; Zhou, J.; Hasan, A.; Karmakar, A. The Potentiality of Rice Husk-Derived Activated Carbon: From Synthesis to Application. Processes 2020, 8, 203. [CrossRef]

159. Ahmed, M.B.; Zhou, J.L.; Ngo, H.H.; Johir, M.A.H.; Sun, L.; Asadullah, M.; Belhaj, D. Sorption of hydrophobic organic contaminants on functionalized biochar: Protagonist role of $\pi-\pi$ electron-donor-acceptor interactions and hydrogen bonds. $J$. Hazard. Mater. 2018, 360, 270-278. [CrossRef]

160. Chen, X.; Zhou, S.; Zhang, L.; You, T.; Xu, F. Adsorption of heavy metals by graphene oxide/cellulose hydrogel prepared from $\mathrm{NaOH}$ /urea aqueous solution. Materials 2016, 9, 582. [CrossRef]

161. Zhang, J.; Cao, Y.; Feng, J.; Wu, P. Graphene-oxide-sheet-induced gelation of cellulose and promoted mechanical properties of composite aerogels. J. Phys. Chem. C 2012, 116, 8063-8068. [CrossRef]

162. Yan, G.; Feng, Y.; Wang, H.; Sun, Y.; Tang, X.; Hong, W.; Zeng, X.; Lin, L. Interfacial assembly of self-healing and mechanically stable hydrogels for degradation of organic dyes in water. Commun. Mater. 2020, 1, 41. [CrossRef]

163. Ma, Y.; Ma, S.; Wu, Y.; Pei, X.; Gorb, S.N.; Wang, Z.; Liu, W.; Zhou, F. Remote control over underwater dynamic attachment/detachment and locomotion. Adv. Mater. 2018, 30, 1801595. [CrossRef] [PubMed]

164. Ostrowska-Czubenko, J.; Gierszewska-Drużyńska, M. Effect of ionic crosslinking on the water state in hydrogel chitosan membranes. Carbohyd. Polym. 2009, 77, 590-598. [CrossRef]

165. Chakma, P.; Konkolewicz, D. Dynamic covalent bonds in polymeric materials. Angew. Chem. Int. Ed. 2019, 58, 9682-9695. [CrossRef]

166. Liu, J.J.; Chu, H.J.; Wei, H.L.; Zhu, H.Z.; Wang, G.; Zhu, J.; He, J. Facile fabrication of carboxymethyl cellulose sodium/graphene oxide hydrogel microparticles for water purification. Rsc Adv. 2016, 6, 50061-50069. [CrossRef]

167. Fei, B.; Wach, R.A.; Mitomo, H.; Yoshii, F.; Kume, T. Hydrogel of biodegradable cellulose derivatives. I. Radiation-induced crosslinking of CMC. J. Appl. Polym. Sci. 2000, 78, 278-283. [CrossRef]

168. Wach, R.A.; Mitomo, H.; Yoshii, F.; Kume, T. Hydrogel of biodegradable cellulose derivatives. II. Effect of some factors on radiation-induced crosslinking of CMC. J. Appl. Polym. Sci. 2001, 81, 3030-3037. [CrossRef]

169. Kono, H.; Fujita, S. Biodegradable superabsorbent hydrogels derived from cellulose by esterification crosslinking with 1,2,3,4butanetetracarboxylic dianhydride. Carbohyd. Polym. 2012, 87, 2582-2588. [CrossRef]

170. Guilherme, M.R.; Campese, G.M.; Radovanovic, E.; Rubira, A.F.; Feitosa, J.P.A.; Muniz, E.C. Morphology and water affinity of superabsorbent hydrogels composed of methacrylated cashew gum and acrylamide with good mechanical properties. Polymer 2005, 46, 7867-7873. [CrossRef]

171. Ye, D.; Chang, C.; Zhang, L. High-Strength and Tough Cellulose Hydrogels Chemically Dual Cross-Linked by Using Low- and High-Molecular-Weight Cross-Linkers. Biomacromolecules 2019, 20, 1989-1995. [CrossRef]

172. Akpomie, K.G.; Dawodu, F.A.; Adebowale, K.O. Mechanism on the sorption of heavy metals from binary-solution by a low cost montmorillonite and its desorption potential. Alex. Eng. J. 2015, 54, 757-767. [CrossRef]

173. Pourjavadi, A.; Tehrani, Z.M.; Salimi, H.; Banazadeh, A.; Abedini, N. Hydrogel nanocomposite based on chitosan-g-acrylic acid and modified nanosilica with high adsorption capacity for heavy metal ion removal. Iran. Polym. J. 2015, 24, 725-734. [CrossRef]

174. Abdelwahab, H.E.; Hassan, S.Y.; Mostafa, M.A.; El Sadek, M.M. Synthesis and characterization of glutamic-chitosan hydrogel for copper and nickel removal from wastewater. Molecules 2016, 21, 684. [CrossRef]

175. Wang, Y.; Zhang, C.; Zhao, L.; Meng, G.; Wu, J.; Liu, Z. Cellulose-based porous adsorbents with high capacity for methylene blue adsorption from aqueous solutions. Fibers Polym. 2017, 18, 891-899. [CrossRef]

176. Salama, A.; Shukry, N.; El-Sakhawy, M. Carboxymethyl cellulose-g-poly(2-(dimethylamino) ethyl methacrylate) hydrogel as adsorbent for dye removal. Int. J. Biol. Macromol. 2015, 73, 72-75. [CrossRef]

177. Cheng, H.-l.; Feng, Q.-h.; Liao, C.-a.; Liu, Y.; Wu, D.-b.; Wang, Q.-g. Removal of methylene blue with hemicellulose/clay hybrid hydrogels. Chin. J. Polym. Sci. 2016, 34, 709-719. [CrossRef]

178. Zhao, L.; Mitomo, H. Adsorption of heavy metal ions from aqueous solution onto chitosan entrapped CM-cellulose hydrogels synthesized by irradiation. J. Appl. Polym. Sci. 2008, 110, 1388-1395. [CrossRef]

179. Liu, J.; Su, D.; Yao, J.; Huang, Y.; Shao, Z.; Chen, X. Soy protein-based polyethylenimine hydrogel and its high selectivity for copper ion removal in wastewater treatment. J. Mater. Chem. A 2017, 5, 4163-4171. [CrossRef]

180. Daochalermwong, A.; Chanka, N.; Songsrirote, K.; Dittanet, P.; Niamnuy, C.; Seubsai, A. Removal of Heavy Metal Ions Using Modified Celluloses Prepared from Pineapple Leaf Fiber. Acs Omega 2020, 5, 5285-5296. [CrossRef]

181. Liu, J.; Chen, T.-W.; Yang, Y.-L.; Bai, Z.-C.; Xia, L.-R.; Wang, M.; Lv, X.-L.; Li, L. Removal of heavy metal ions and anionic dyes from aqueous solutions using amide-functionalized cellulose-based adsorbents. Carbohyd. Polym. 2020, 230, 115619. [CrossRef]

182. Mahmoodi, N.M.; Hayati, B.; Arami, M. Textile Dye Removal from Single and Ternary Systems Using Date Stones: Kinetic, Isotherm, and Thermodynamic Studies. J. Chem. Eng. Data 2010, 55, 4638-4649. [CrossRef]

183. Liu, P.; Peng, J.; Li, J.; Wu, J. Radiation crosslinking of CMC-Na at low dose and its application as substitute for hydrogel. Radiat. Phys. Chem. 2005, 72, 635-638. [CrossRef]

184. Chiou, M.-S.; Li, H.-Y. Equilibrium and kinetic modeling of adsorption of reactive dye on cross-linked chitosan beads. J. Hazard. Mater. 2002, 93, 233-248. [CrossRef] 
185. Dai, H.; Huang, Y.; Zhang, H.; Ma, L.; Huang, H.; Wu, J.; Zhang, Y. Direct fabrication of hierarchically processed pineapple peel hydrogels for efficient Congo red adsorption. Carbohyd. Polym. 2020, 230, 115599. [CrossRef]

186. Cao, J.; Fei, D.; Tian, X.; Zhu, Y.; Wang, S.; Zhang, Y.; Mao, Q.; Sun, M. Novel modified microcrystalline cellulose-based porous material for fast and effective heavy-metal removal from aqueous solution. Cellulose 2017, 24, 5565-5577. [CrossRef]

187. Solomon, T. The Definition and Unit of Ionic Strength. J. Chem. Educ. 2001, 78, 1691. [CrossRef]

188. Muthukumar, M.; Sargunamani, D.; Selvakumar, N.; Nedumaran, D. Effect of Salt Additives on Decolouration of Acid Black 1 Dye Effluent by Ozonation; CSIR: New Delhi, India, 2004; Volume 11, pp. 612-616.

189. Metin, A.e.l.U.; Çiftçi, H.; Alver, E. Efficient removal of acidic dye using low-cost biocomposite beads. Ind. Eng. Chem. Res. 2013, 52, 10569-10581. [CrossRef]

190. Mahmoodi, N.M.; Salehi, R.; Arami, M.; Bahrami, H. Dye removal from colored textile wastewater using chitosan in binary systems. Desalination 2011, 267, 64-72. [CrossRef]

191. Alam, M.N.; Islam, M.S.; Christopher, L.P. Sustainable Production of Cellulose-Based Hydrogels with Superb Absorbing Potential in Physiological Saline. Acs Omega 2019, 4, 9419-9426. [CrossRef]

192. Zheng, Y.; Hua, S.; Wang, A. Adsorption behavior of $\mathrm{Cu} 2+$ from aqueous solutions onto starch-g-poly (acrylic acid)/sodium humate hydrogels. Desalination 2010, 263, 170-175. [CrossRef]

193. Antic, K.M.; Babic, M.M.; Vukovic, J.S.; Onjia, A.E.; Filipović, J.M.; Tomic, S.L. Removal of Pb2+ from aqueous solution by P (HEA/IA) hydrogels. Hem. Ind. 2016, 70, 695-705. [CrossRef]

194. Ma, J.; Zhou, G.; Chu, L.; Liu, Y.; Liu, C.; Luo, S.; Wei, Y. Efficient removal of heavy metal ions with an EDTA functionalized chitosan/polyacrylamide double network hydrogel. Acs Sustain. Chem. Eng. 2017, 5, 843-851. [CrossRef]

195. Hwang, D.C.; Damodaran, S. Metal-chelating properties and biodegradability of an ethylenediaminetetraacetic acid dianhydride modified soy protein hydrogel. J. Appl. Polym. Sci. 1997, 64, 891-901. [CrossRef]

196. Jiang, L.; Liu, P. Design of magnetic attapulgite/fly ash/poly (acrylic acid) ternary nanocomposite hydrogels and performance evaluation as selective adsorbent for Pb2+ ion. Acs Sustain. Chem. Eng. 2014, 2, 1785-1794. [CrossRef]

197. Dwivedi, C.; Pathak, S.K.; Kumar, M.; Tripathi, S.C.; Bajaj, P.N. Preparation and characterization of potassium nickel hexacyanoferrate-loaded hydrogel beads for the removal of cesium ions. Environ. Sci. Water Res. Technol. 2015, 1, 153-160. [CrossRef]

198. Fritz, J.S. Factors affecting selectivity in ion chromatography. J. Chromatogr. A 2005, 1085, 8-17. [CrossRef] 